\title{
29. CALCAREOUS NANNOFOSSIL BIOSTRATIGRAPHY AND SEDIMENT ACCUMULATION OF TURBIDITE SEQUENCES ON THE MADEIRA ABYSSAL PLAIN, SITES 950-952 ${ }^{1}$
}

\author{
Richard W. Howe ${ }^{2}$ and JoAnne Sblendorio-Levy ${ }^{3}$
}

\begin{abstract}
Drilling on the Madeira Abyssal Plain during Leg 157 penetrated deep into the sequence of interbedded turbidites and pelagic sediments that underlie the plain. The turbidites generally have abundant and well-preserved calcareous nannofossil assemblages, with the interbedded pelagic sediments having variable preservation and abundance of nannofossils dependent on $\mathrm{CaCO}_{3}$ content. Poor preservation in pelagic sediments from the Paleogene and Miocene necessitated the use of nannofossil datums from turbidites to construct a consistent biostratigraphy.

Site 950 records Neogene turbidite deposition of organic carbon-rich, volcaniclastic-rich, and highly calcareous turbidites from different sources around the plain with thin interbedded pelagic red clays, marls, and oozes. A disconformity separates the upper part of Zone CN3 from a single turbidite belonging to Zone CN2, below which a major disconformity separates Zone CN2 from Subzone CP19b, at the top of the Oligocene. Throughout the Oligocene and late Eocene, down to Subzone CP15a, the sequence comprises thin calcareous turbidites and thick pelagic red clays. Sites 951 and 952 only penetrated as deep as Zone CN3 and have similar sequences to the Neogene section of Site 951. Total sediment and pelagic sediment accumulation rates have varied dramatically with time, with low rates in the Paleogene section of Site 950 rising significantly throughout the Neogene. Sites 951 and 952 have much higher rates in the lower and middle Miocene than Site 950, above which all three sites have broadly similar rates.
\end{abstract}

\section{INTRODUCTION}

The Canary Basin has a surface area of 3.36 by $10^{6} \mathrm{~km}^{2}$ and is bounded by the Mid-Atlantic Ridge to the west, the Azores-Gibraltar Rise to the north, the Madeira-Tore Rise and northwest African Continental Rise to the east, and the Cape Verde Rise to the south (Rothwell et al., 1992). The Madeira Abyssal Plain (MAP; see Fig. 1) forms the deepest part of the basin at a depth of $\sim 5400 \mathrm{~m}$, with a surface area of $\sim 68,000 \mathrm{~km}^{2}$. Sites 950,951 , and 952 were drilled on the MAP during Ocean Drilling Program (ODP) Leg 157 to examine the link between sea-level changes and sediment stability on the African continental margin and the flanks of the volcanic Canary Islands. Much of the sediment derived from mass-wasting events on the basin margins, including the northwest African margin, the Great Meteor Seamount Chain, and the Canary Islands (Fig. 1), is deposited on the MAP as turbidites, where it provides an accurate record of such events. These turbidites comprise numerous laterally extensive layers up to several meters thick, composed of ungraded clayey nannofossil mixed sediment and nannofossil clay sediments, with minor silty or sandy bases.

The Quaternary turbidite sequence on the MAP has been studied intensively (see synthesis by Weaver et al., 1989), with a detailed geological history being determined for the last 730 k.y. (Weaver et al., 1992, 1995). During the Quaternary, these turbidites were emplaced at frequencies related to climate and sea-level change (Weaver and Kuijpers, 1983; Weaver et al., 1992), with each sea-level change (both rises and falls) generally associated with a single turbidite. Most of the turbidites can be grouped into three compositionally distinct types, each with different source areas (Jarvis and Higgs, 1987;

${ }^{1}$ Weaver, P.P.E., Schmincke, H.-U., Firth, J.V., and Duffield, W. (Eds.), 1998. Proc. ODP, Sci. Results, 157: College Station, TX (Ocean Drilling Program).

${ }^{2}$ Challenger Division for Seafloor Processes, Southampton Oceanography Centre, Southampton, Hampshire SO14 3ZH, United Kingdom. (Present address:Department of Geology and Geophysics, University of Western Australia, Nedlands, WA 6907, Australia).rhowe@uniwa.uwa.edu.au

${ }^{3} 6111$ Yarwell, Houston, TX 77096, U.S.A.
De Lange et al., 1987): (1) volcanic turbidites, which are rich in volcaniclastic material derived from the volcanic Canary Islands and Madeira; (2) organic turbidites, which have high total organic carbon contents and originate from upwelling areas on the African shelf; and (3) calcareous turbidites derived from pelagic carbonate sediments accumulating on the volcanic seamounts of the Great Meteor Seamount Chain.

The floor of the MAP at present, and during previous PlioceneQuaternary interglacial periods, lies between the lysocline and calcite compensation depth (CCD), which allows calcareous pelagic sedi-

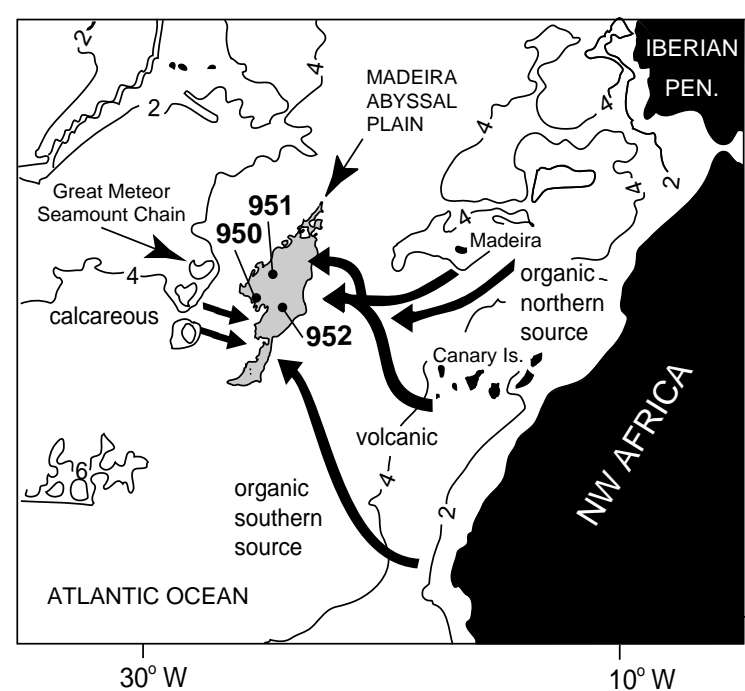

$40^{\circ} \mathrm{N}$

Figure 1. Map showing the location of the Madeira Abyssal Plain (shown as the gray area enclosed by the 5-km bathymetric contour) and Sites 950, 951, and 952. The sources and directions of emplacement of the Quaternary turbidites on the Plain are shown by heavy arrows. Bathymetric contour interval is $2 \mathrm{~km}$.

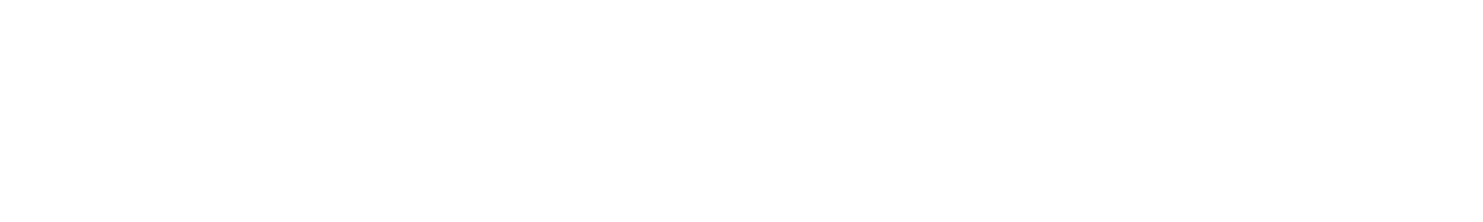


ment to accumulate between turbidite events. These interbedded pelagic sediments contain abundant and generally well-preserved nannofossils from which an accurate biostratigraphy can be obtained. During the peak of Pliocene and Quaternary glacial periods, the production of North Atlantic Deep Water (NADW) was suppressed, allowing corrosive Antarctic Bottom Water to replace the noncorrosive NADW (Crowley, 1983; Raymo, 1994). This caused the CCD to rise above the level of the MAP, with the increased dissolution resulting in the deposition of red clay. Before the Pliocene, back to at least the late Eocene, the floor of the MAP was permanently below the level of the $\mathrm{CCD}$, and only red clay barren of calcareous microfossils was able to accumulate.

As an accurate chronostratigraphy of the sequence is important to meet the aims of the MAP project, it has been necessary to examine the turbidites in the late Eocene to Miocene sequence, which were very broadly zoned with the shipboard biostratigraphic data. Examination of many additional samples, and reexamination of shipboard samples, has shown that these turbidites mostly contain abundant and well-preserved nannofossil assemblages in contrast to the interbedded pelagic sediments. Pelagic sediments in the overlying PliocenePleistocene sequence contain abundant and well-preserved nannofossils and were well dated by the shipboard biostratigraphy (see Schmincke, Weaver, Firth, et al., 1995), so they were not reexamined here.

Turbidites are not generally suitable for accurate biostratigraphy, as they can contain significant numbers of reworked nannofossils, making highest appearance datums unreliable. However, studies of Quaternary turbidites on the MAP by Weaver and Thomson (1993) and Weaver $(1994,1993)$ have shown that a biostratigraphy accurate to $50-500 \mathrm{k} . \mathrm{y}$. can be obtained, particularly from organic and volcanic turbidites. Their findings can be summarized as follows: the source areas of organic and volcanic turbidites deposited on the MAP are the northwest African margin and the flanks of the Canary Islands, respectively. These areas are characterized by high sedimentation rates, up to $15 \mathrm{~m} / \mathrm{m}$.y. under upwelling cells on the African margin (Weaver, 1994), and up to $118 \mathrm{~m} / \mathrm{m}$.y. on the flanks of Gran Canaria, the largest of the Canary Islands (Shipboard Scientific Party, 1995d).

These high sedimentation rates lead to an unstable sediment pile that is prone to mass-wasting events. These events are triggered by changes in sea level and perhaps also earthquakes associated with volcanism on the Canary Islands. Knowing the abundance ratios of several important nannofossil species in each oxygen isotope stage from pelagic sediments near the MAP, Weaver (1994) was able to construct synthetic mixtures of nannofossils that modeled the nannofossil ratios of turbidites resulting from the mass wasting of sediment bodies of various thicknesses and shapes. Comparing these synthetic ratios with those from actual turbidites on the MAP, Weaver (1994) was able to show that the eroded areas on the shelf must have been tabular in shape, and that they contained sediment with a short age range of 50-500 k.y. Synthetic ratios calculated for such bodies matched the actual turbidite ratios much better than those from wedge-shaped, or irregular-shaped bodies, which, as they erode deeper into the sediment pile, give a broader range in coccolith ages.

Weaver and Thomson (1993) were also able to show that the turbidites were nearly nonerosive during their transport down the continental rise and slope to the MAP and across it, with no more than $12 \%$ of the volume of the turbidite derived from the erosion of underlying sediment. Weaver (1994) also found that calcareous turbidites derived from the seamounts to the west of the MAP contained a greater age range of material, up to 2-3 m.y., reducing their suitability for biostratigraphy. This was thought to be because the flows from the seamounts were produced by deeper erosion, or alternatively, because frequent small flows produced many minor hiatuses, effectively condensing the sequence. Such a condensed sequence would produce a greater age range of material for a slump of a given thickness.
These results suggest that a workable biostratigraphy should be obtainable from pre-Quaternary organic and volcanic turbidites, which in the MAP sites have similar lithologies, thicknesses, and sources, and approximately similar frequencies of emplacement to those from the Quaternary. Lowest occurrences (LO's) of nannofossil species have been used wherever possible, as these are not affected by reworking. Several zonal boundaries have been approximated by secondary events (usually LO's), where the event marking the boundary is a highest occurrence, and there is evidence for reworking. Obviously, ages derived from highest occurrences (HO's) in turbidites are going to represent maximum ages, with the actual emplacement age of the turbidite being somewhat younger, but as Weaver and Thomson (1993) and Weaver (1994) have shown, these ages are unlikely to be in error by $>500$ k.y. This seems an acceptable degree of error, given that many early and middle Miocene nannofossil and paleomagnetic datums are poorly correlated to the chronometric scale and have a similar error of as much as $\pm 500 \mathrm{k} . \mathrm{y}$. (Young et al., 1994).

Accordingly, this paper aims to construct a consistent nannofossil biostratigraphy of the late Eocene-Miocene turbidite sequences on the MAP to enable correlation between the three sites and to date the timing of various changes in the type and frequency of turbidite emplacement on the MAP (see Lebreiro et al., Chap. 30, this volume). This biostratigraphy is then combined with the Pliocene-Pleistocene shipboard biostratigraphy and used to construct age-depth plots from which sedimentation rates are calculated and their implications considered.

\section{METHODS}

The nannofossil biostratigraphy presented here is based on examination of smear slides of unprocessed sediment using transmitted, cross-polarized and phase-contrast illumination with a light microscope at a magnification of $1250 \times$. Taxa on the range charts in this paper are listed in Tables 1-4 in the back-pocket foldout (this volume). Bibliographic references to these taxa can to be found in PerchNielsen (1985), with any references not listed therein cited in the references of this paper. The biostratigraphic zonation scheme used here is that of Bukry (1973; 1975), which was given code numbers by, Okada and Bukry (1980). This zonation is widely used as a framework for the biostratigraphy of Cenozoic low, mid-latitude, openmarine sediments. Correlation of the zonation to the time scale of Cande and Kent (1992) is taken from Young et al. (1994) for the Neogene, and Wei and Peleo-Alampay (1993) for the Paleogene. The only modification to these correlations is the adoption of the ranges of Reticulofenestra rotaria and Amaurolithus amplificus, determined by Wei (1996) from the equatorial Indian Ocean. According to Young et al. (1994), 400 k.y. separates the ranges of these species. In the holes examined here, the ranges overlap substantially, which is more consistent with the ranges proposed by Wei (1996). This overlap could be caused by reworking, but as both these species are rare throughout their ranges (particularly A. amplificus), this is considered unlikely.

All depths below seafloor in this paper have been calculated from the revised depths of Lebreiro et al. (Chap. 30, this volume). Semiquantitative letter codes are used on the range charts to denote nannofossil abundance and preservation. Overall nannofossil abundance in a sample was recorded as follows:

$\mathrm{VH}=$ very high, $>100$ specimens per field of view (FOV);

$\mathrm{H}=$ high, 50-100 specimens per FOV;

$\mathrm{M}=$ moderate $10-50$ specimens per FOV;

$\mathrm{L}=$ low, $1-10$ specimens per FOV; and

$\mathrm{VL}=$ very low, 1 specimen per $1-10$ FOV's. 
Individual species abundances were recorded as follows:

$\mathrm{A}=$ abundant, $>100$ specimens per FOV;

$\mathrm{C}=$ common, $11-100$ specimens per FOV;

$\mathrm{F}=$ few, $1-10$ specimens per $\mathrm{FOV}$;

$\mathrm{R}=$ rare, 1 specimen in 10 FOV's; and

$\mathrm{S}=$ single, only a single specimen observed.

As nannofossil assemblages in a sample can show overgrowth of some species and dissolution of others, only the overall preservation state of the assemblage is recorded here, as follows:

$\mathrm{G}=$ good, whole assemblage is well preserved, with the diagnostic features of most species preserved;

$\mathrm{M}=$ moderate, with some dissolution and/or overgrowth, but most species still identifiable; and

$\mathrm{P}=$ poor, severe dissolution and/or overgrowth, with only a few species identifiable to species level.

\section{SITE SUMMARIES}

\section{Site 950}

Site 950 lies in the western part of the MAP at $31^{\circ} 9.011^{\prime} \mathrm{N}$, $25^{\circ} 36.004^{\prime} \mathrm{W}$ in the Cruiser Fracture Zone Valley (see Searle, 1987), at a water depth of $5437.8 \mathrm{~m}$. Hole $950 \mathrm{~A}$ penetrated $381.3 \mathrm{~m}$ of late Eocene-Holocene sediment from 17 advanced piston corer (APC) cores (0-154.2 meters below seafloor [mbsf]) and 24 extended core barrel (XCB) cores (154.2-372.1 mbsf), with 88.9\% recovery (Shipboard Scientific Party, 1995a). The distribution and biostratigraphy of Miocene nannofossils from Hole 950A is shown in Table 1 and that of Paleogene nannofossils is shown on Table 2 (both on the backpocket foldout, this volume) The biostratigraphy and lithology of the hole is summarized in Figure 2.

\section{Late Miocene}

Most of the samples examined from the middle and late Miocene are from organic and calcareous turbidites which generally contain abundant and moderately well-preserved nannofossils. Some of the organic turbidites contain high levels of total organic carbon, typically $\sim 1.5 \%-2 \%$ (Shipboard Scientific Party, 1995a). These turbidites are dark green in color and generally have low carbonate contents and poorly preserved, low-abundance nannofossil assemblages. Samples from the pelagic clays between the turbidites are barren or have very low abundances of poorly preserved nannofossils, which generally are biostratigraphically nondiagnostic. The top of the Miocene is marked by the highest significant occurrence of the marker species for Subzone CN9b, Discoaster quinqueramus, in Sample 157-950A$21 \mathrm{X}-5,108 \mathrm{~cm}$ (185.49 mbsf). A single specimen of D. quinqueramus in Sample 157-950A-20X-6, $5.5 \mathrm{~cm}$ (176.47 mbsf) is considered to be reworked. This is supported by the LO of Amaurolithus tricorniculatus in this sample, which according to Perch-Nielsen (1985), first occurs very close to the top of CN9b.

Several useful secondary events occur within CN9b. The HO's of A. amplificus and Reticulofenestra rotaria occur in Sample 157950A-23X-1, $90 \mathrm{~cm}$ (198.70 mbsf). According to Wei (1996), these two events are separated by 340 k.y., so their concurrent HO is probably caused by the reworking of $R$. rotaria, which is significantly more common than the rare A. amplificus. The LO of A. amplificus occurs in Sample 157-950A-25X-1, $41.5 \mathrm{~cm}$ (217.54 mbsf), with the reoccurrence of large Reticulofenestra pseudoumbilicus (R. pseudoumbilicus larger than $7 \mu \mathrm{m}$ have an absence interval, or paracme in the late Miocene; see Young et al., 1994) occurring in Sample 157-950A$25 \mathrm{X}-3,49 \mathrm{~cm}$ (220.61 mbsf). The LO of Amaurolithus delicatus occurs in Sample 157-950A-26X-3, $107 \mathrm{~cm}$ (230.79 mbsf), with the LO of $R$. rotaria occurring just below in Sample 26X-4, $14 \mathrm{~cm}(231.36$ mbsf). The base of CN9b is marked in Sample 157-950A-26X-4, 94 $\mathrm{cm}(232.16 \mathrm{mbs})$ by the LO of Amaurolithus primus, with the $\mathrm{HO}$ of the enigmatic species Minylitha convallis occurring in the same sample. Subzone CN9a occurs from Sample 157-950A-26X-5, $95.5 \mathrm{~cm}$ ( $233.68 \mathrm{mbsf}$ ) down, with its base marked by the LO of $D$. quinqueramus, and also Discoaster berggrenii, in Sample 157-950A-27X-3, $23 \mathrm{~cm}(239.63 \mathrm{mbsf})$.

Subzone CN8b occurs from Sample 27X-4, $70 \mathrm{~cm}$ (241.54 mbsf), through $28 \mathrm{X}-1,32 \mathrm{~cm}$ (246.32 mbsf). The top of subzone CN8a occurs in Sample 157-950A-28X-2, $65.5 \mathrm{~cm}$ (248.16 mbsf), and is approximated here by the $\mathrm{HO}$ of large $R$. pseudoumbilicus, which according to Young et al. (1994), occurs at nearly the same time as the LO of Discoaster loeblichii, the marker species for the top of CN8a. This is the only sample belonging to Subzone CN8a, with the LO of Discoaster pentaradiatus in this sample used here to approximate the base of the zone, rather than the HO of the marker species Discoaster hamatus, which occurs in low abundances above this level and is considered reworked. The LO of $D$. pentaradiatus is gradational and occurs within Zone CN8, but not within Zone CN7 according to Young et al. (1994).

Zone CN7 occurs from Sample 157-950A-28X-2, $147 \mathrm{~cm}$ (248.97 mbsf) through Sample 28X-CC, $32 \mathrm{~cm}$ (249.88 mbsf), where its base is marked by the LO of the highly distinctive D. hamatus. Two secondary events in CN7 are the LO's of M. convallis and Discoaster neohamatus in Sample 157-950A-28X-2, $147 \mathrm{~cm}$ (248.97 mbsf). The top of Zone CN6 occurs in Sample 157-950A-29X-2, $29.5 \mathrm{~cm}$ (257.50 mbsf). The LO of Catinaster coalitus, which occurs in Sample 157-950A-29X-4, $41 \mathrm{~cm}$ (260.60 mbsf), marks the base of CN6, which approximates the beginning of the late Miocene.

\section{Middle Miocene}

The top of Zone CN5b occurs in Sample 157-950A-29X-6, $53 \mathrm{~cm}$ ( $263.73 \mathrm{mbsf}$ ), with the base of the zone marked by the LO of Discoaster kugleri in Sample 30X-5, $85 \mathrm{~cm}$ (272.22 mbsf). Subzone CN5a occurs from Sample 157-950A-30X-6, $95 \mathrm{~cm}$ (273.82 mbsf), through Sample 32X-2, $30 \mathrm{~cm}$ (286.57 mbsf), where the base of the zone is approximated by the LO of Triquetrorhabdulus rugosus. According to Young et al. (1994), the LO of T. rugosus occurs at 13.0 Ma, somewhat above the zonal event (the HO of Sphenolithus heteromorphus), which occurs at $13.6 \mathrm{Ma}$ and is considered unreliable here because of reworking.

A major coarse-grained, graded calcareous turbidite occurs from Sections 157-950A-34X-2, $20 \mathrm{~cm}$, through 35X-CC, $38 \mathrm{~cm}$ (305.70$314.81 \mathrm{mbsf}$ ), and is the deepest turbidite that can be correlated between all three MAP sites (see Lebreiro et al., Chap. 30, this volume). This important unit has been named the "Cruiser" turbidite, after the seamount closest to Site 950, from where it probably originated. The top of Zone CN4 occurs in Sample 157-950A-32X-6, $19 \mathrm{~cm}$ (292.38 mbsf), with the base approximated here by the LO of Discoaster signus in Sample 157-950A-34X-2, $50.5 \mathrm{~cm}$ (306.00 mbsf), a sample from the Cruiser turbidite. The zonal event for the base of this zone, the $\mathrm{HO}$ of Helicosphaera ampliaperta, is clearly subject to reworking. A deeper sample from the Cruiser turbidite, Sample 157-950A$35 \mathrm{X}-1,53 \mathrm{~cm}$ (314.13 mbsf), could not be conclusively assigned to either Zones CN3 or 4, because of a low abundance assemblage of poorly to moderately preserved nannofossils.

\section{Early Miocene}

The preservation and abundance of nannofossils in early Miocene sediments varies from poor to moderate, with generally very low to low abundances. Below the Cruiser turbidite, there is a thin section of pelagic clays, sandy calcareous turbidites, and organic turbidites (Section 157-950A-36X-1, $18 \mathrm{~cm}$, through 36X-2, $93 \mathrm{~cm}, 323.31-$ 


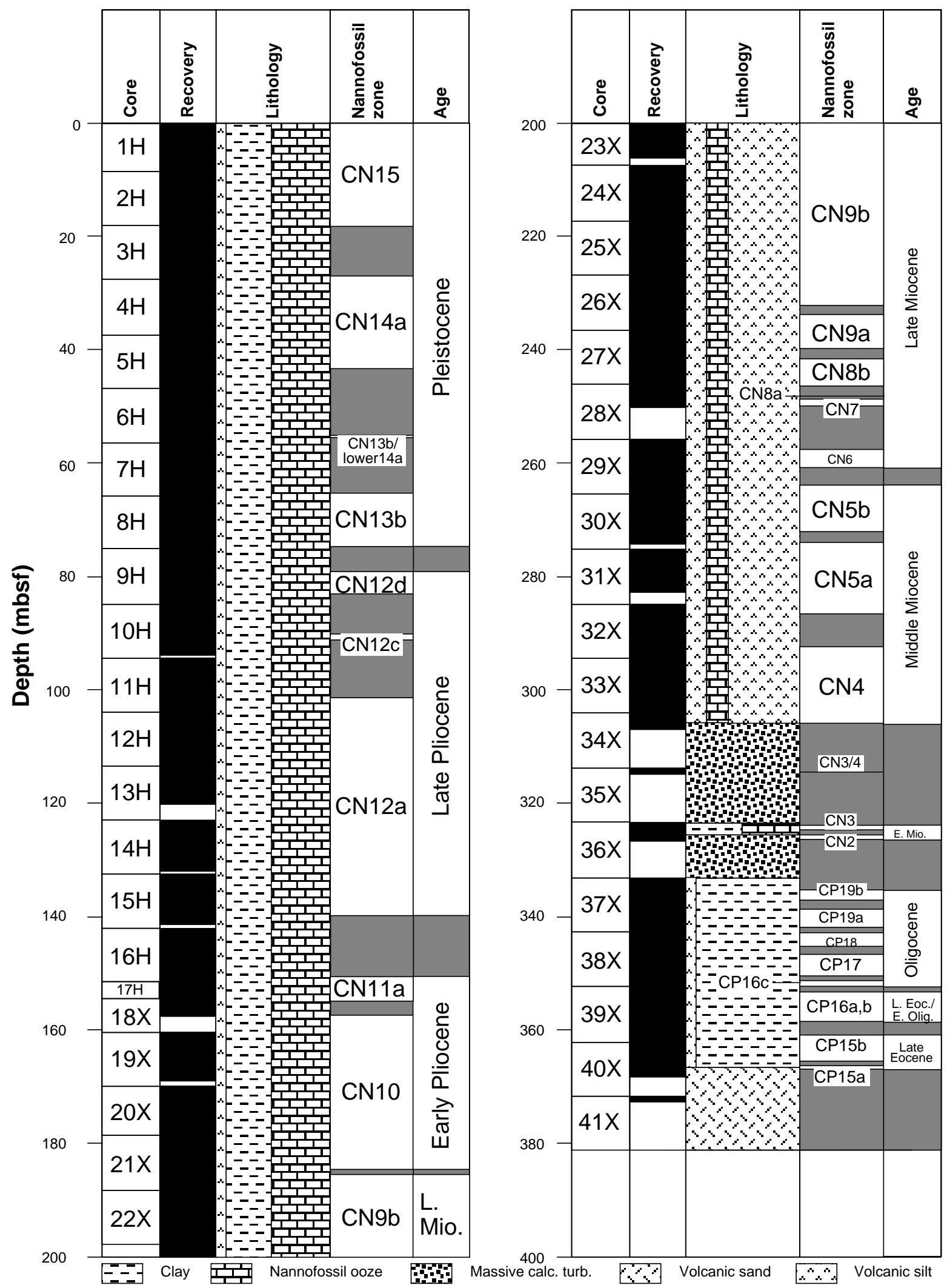

Figure 2. Nannofossil zonation and schematic lithology of Hole 950A. Pliocene-Quaternary data are from Schmincke, Weaver, Firth, et al. (1995). 
$325.46 \mathrm{mbsf}$ ). Two samples from turbidites in this section, Samples 157-950A-36X-1, $55 \mathrm{~cm}$ (323.68 mbsf), and 157-950A-36X-2, $7 \mathrm{~cm}$ (324.60 mbsf), contain S. heteromorphus and Discoaster exilis in the absence of D. signus and are assigned to the upper part of Zone CN3. Below this, there is a section of very poor core recovery, with thin calcareous sands above and below (Section 157-950A-36X-2, $93 \mathrm{~cm}$, through $37 \mathrm{X}-1,0 \mathrm{~cm}$ (325.46-333.00 mbsf), which is interpreted to be a single sandy calcareous turbidite (Lebreiro et al., Chap. 30, this volume).

Two samples from the top and bottom of this unit, Samples 157950A-36X-2, $109 \mathrm{~cm}$ (325.62 mbsf), and 36X-CC, $25 \mathrm{~cm}$ (326.29 mbsf), contain Sphenolithus belemnos in the absence of Sphenolithus heteromorphus and are assigned to Zone CN2. Accordingly, a short hiatus or erosional disconformity of $\sim 1.1$ m.y. (17.1-18.2 Ma) seems to be present between the pelagic clays and turbidites of upper Zone $\mathrm{CN} 3$ and the single sandy calcareous turbidite belonging to Zone CN2. Sample 157-950A-36X-2, $109 \mathrm{~cm}$ (325.62 mbsf), from the turbidite contains common reworked Oligocene species, so it seems likely that this coarse-grained unit was erosive during emplacement. This erosion probably caused a significant disconformity with the Eocene and Oligocene sediments below, with Zone CN1 not being present. The break in time across this disconformity is $\sim 8.3 \mathrm{~m} . \mathrm{y}$., from 18.2 to $26.5 \mathrm{Ma}$.

Biogenic siliceous debris, mainly comprising diatoms and sponge spicules, is present in rare to common abundances in turbidites between Samples 157-950A-31X-5, $27 \mathrm{~cm}$ (281.15 mbsf), and 36XCC, $25 \mathrm{~cm}$ (326.29 mbsf), in Zones CN3 and 4, and the base of Subzone CN5a. This siliceous debris probably reflects upwelling-related high productivity on the African margin, where many of these turbidites are derived from.

\section{Oligocene}

Below the major disconformity at the base of the Miocene, the sequence comprises pelagic red clays, thin calcareous turbidites, and ash layers. Pelagic clays examined from this sequence have very low carbonate contents and are barren of nannofossils, with the calcareous turbidites generally having moderate to highly abundant, moderately well-preserved assemblages. Only two samples contain nannofossils indicating Subzone CP19b, Samples 157-950A-37X-2, 65.5 $\mathrm{cm}$ (335.09 mbsf), and 37X-3, $122 \mathrm{~cm}$ (337.10 mbsf), which contain Sphenolithus ciperoensis. Single specimens of $S$. distentus are present in each sample, but are considered reworked. Subzone CP19a occurs between Samples 157-950A-37X-4, $128.5 \mathrm{~cm}$ (338.62 mbsf), and $37 \mathrm{X}-7,9 \mathrm{~cm}$ (341.83 mbsf), where the base of the zone is marked by the LO of $S$. ciperoensis. The LO of S. distentus occurs in Sample 157-950A-38X-2, $115 \mathrm{~cm}$ (345.21 mbsf), and marks the base of Zone CP18, with the top of the zone occurring in Sample 37X-CC, $45 \mathrm{~cm}$ (342.59 mbsf).

Zone CP17 occurs from Sample 157-950A-38X-3, $112 \mathrm{~cm}$ (346.65 mbsf), through 38X-6, $46 \mathrm{~cm}$ (350.42 mbsf). The top of Subzone CP16c is marked in Sample 157-950A-38X-6, $131 \mathrm{~cm}(351.25$ mbsf), by the HO of Reticulofenestra umbilicus. This event is difficult to define here, as $R$. umbilicus is reworked in low abundances as high as Sample 157-950A-37X-7, $9 \mathrm{~cm}$ (341.83 mbsf), so we have taken the boundary to be at the highest sample in which $R$. umbilicus is present in appreciable abundance. The base of Subzone CP16c occurs in Sample 157-950A-38X-CC, $42 \mathrm{~cm}$ (352.29 mbsf). Subzones $\mathrm{CP} 16 \mathrm{a}$ and 16b could not be separated here as the boundary event, and the $\mathrm{HO}$ of common Clausicoccus fenestratus (Ericsonia subdisticha of many authors) could not be accurately determined, presumably because of reworking. The top of Subzones CP16a and 16b are marked by the $\mathrm{HO}$ of Coccolithus formosus, which occurs in Sample 157-950A-39X-1, $89 \mathrm{~cm}$ (353.18 mbsf). As with the HO of R. umbilicus, $C$. formosus has been reworked, so we have taken the boundary at the highest sample in which $C$. formosus is present in appreciable abundance. The base of Subzones CP16a and 16b occur in Sample 157-950A-39X-5, $29 \mathrm{~cm}$ (358.44 mbsf).

\section{Late Eocene}

The top of Subzone CP15b is marked by the HO of Discoaster saipanensis. This species is reworked, so the boundary here is marked by the abrupt decline in its abundance from common to rare above Sample 157-950A-39X-6, $130 \mathrm{~cm}$ (360.93 mbsf). The base of this subzone is marked in Sample 157-950A-40X-3, $38 \mathrm{~cm}(365.38$ mbsf), by the LO of Isthmolithus recurvus. The top of Subzone CP15a occurs in Sample 157-950A-40X-3, $130 \mathrm{~cm}$ (366.30 mbsf). The base of the subzone could not be determined as the HO of Chiasmolithus grandis, because the event marking this boundary was not observed. Sandy and silty volcanic turbidites occur near the base of the hole. A sample from the top of this sequence, Sample 157950A-40X-4, $17 \mathrm{~cm}$ (366.67 mbsf), contained a nannofossil assemblage belonging to Subzone CP15a. Sample 157-950A-41X-1, 2.5 cm (371.59 mbsf), is a barren pelagic clay and was probably caved from uphole. These sandy and silty turbidites contain no in-place pelagic clays, were probably deposited in a short space of time, and so probably still belong to $\mathrm{CP} 15 \mathrm{a}$.

\section{Site 951}

Site 951 lies in the northwestern part of the MAP at $32^{\circ} 1.896^{\prime} \mathrm{N}$, $24^{\circ} 52.232^{\prime} \mathrm{W}$, at a water depth of $5436.8 \mathrm{~m}$ in the Charis Fracture Zone Valley (see Searle, 1987). Hole 951A penetrated $256.60 \mathrm{~m}$ of middle Miocene to Holocene sediment from 13 APC cores (0-117.0 mbsf) and $15 \mathrm{XCB}$ cores (117.0-256.6 mbsf), with $98 \%$ recovery. The hole was abandoned following technical problems, and Hole 951B was begun. This hole was washed down to $255 \mathrm{mbsf}$, and then $10 \mathrm{XCB}$ cores were recovered down to $351.5 \mathrm{mbsf}$, with $87.6 \%$ recovery (Shipboard Scientific Party, 1995b). The distribution and biostratigraphy of nannofossils from Holes 951A and 951B is shown in Table 3 (back-pocket foldout, this volume), and the biostratigraphy is summarized in Figure 3.

\section{Late Miocene}

The middle and late Miocene sequence at Site 951 is similar to that of Site 950, with similar lithologies, nannofossil abundance and preservation, and a similar sequence of nannofossil events. The HO of D. quinqueramus occurs in Sample 157-951A-21X-4, $98 \mathrm{~cm}$ (184.88 mbsf), and marks the top of Subzone CN9b. As at Site 950, several useful secondary events occur in CN9b. The HO's of A. amplificus and $R$. rotaria occur together in Sample 157-951A-22X-4, 35 cm (193.80 mbsf). The LO of A. amplificus occurs in Sample 157951A-24X-6, $102 \mathrm{~cm}$ (216.82 mbsf), with the reoccurrence of large $R$. pseudoumbilicus occurring in the same sample. The LO of A. delicatus occurs in Sample 157-951A-25X-1, $91 \mathrm{~cm}$ (218.87 mbsf), with the LO of $R$. rotaria occurring in Sample 25X-CC, $20 \mathrm{~cm}(227.45$ mbsf). The LO of A. primus in Sample 157-951A-26X-1, $105 \mathrm{~cm}$ (228.67 mbsf), marks the base of CN9b, with the $\mathrm{HO}$ of $M$. convallis occurring in the same sample. Subzone CN9a extends from Sample 157-951A-26X-1, $127 \mathrm{~cm}$ (228.89 mbsf), through Sample 26X-4, 56 $\mathrm{cm}$ (232.66 mbsf), where its base is marked by the LO of $D$. quinqueramus. The top of Subzone CN8b occurs in Sample 157-950A$26 \mathrm{X}-5,71 \mathrm{~cm}(234.31 \mathrm{mbsf})$. The base of the zone is approximated by the temporary HO of large R. pseudoumbilicus in Sample 157951A-27X-1, $97 \mathrm{~cm}$ (238.16 mbsf). The top of Subzone CN8a occurs in Sample 157-951A-27X-1, $97 \mathrm{~cm}$ (238.16 mbsf). The base of Subzone CN8a and all of Zone CN7 are not defined here because of an interval of missing core at the base of Sections 157-951A-26X-6 and $26 \mathrm{X}-7$, and a highly disturbed interval in the upper part of Section 27X-1. Only a single sample was examined from Zone CN6, Sample 

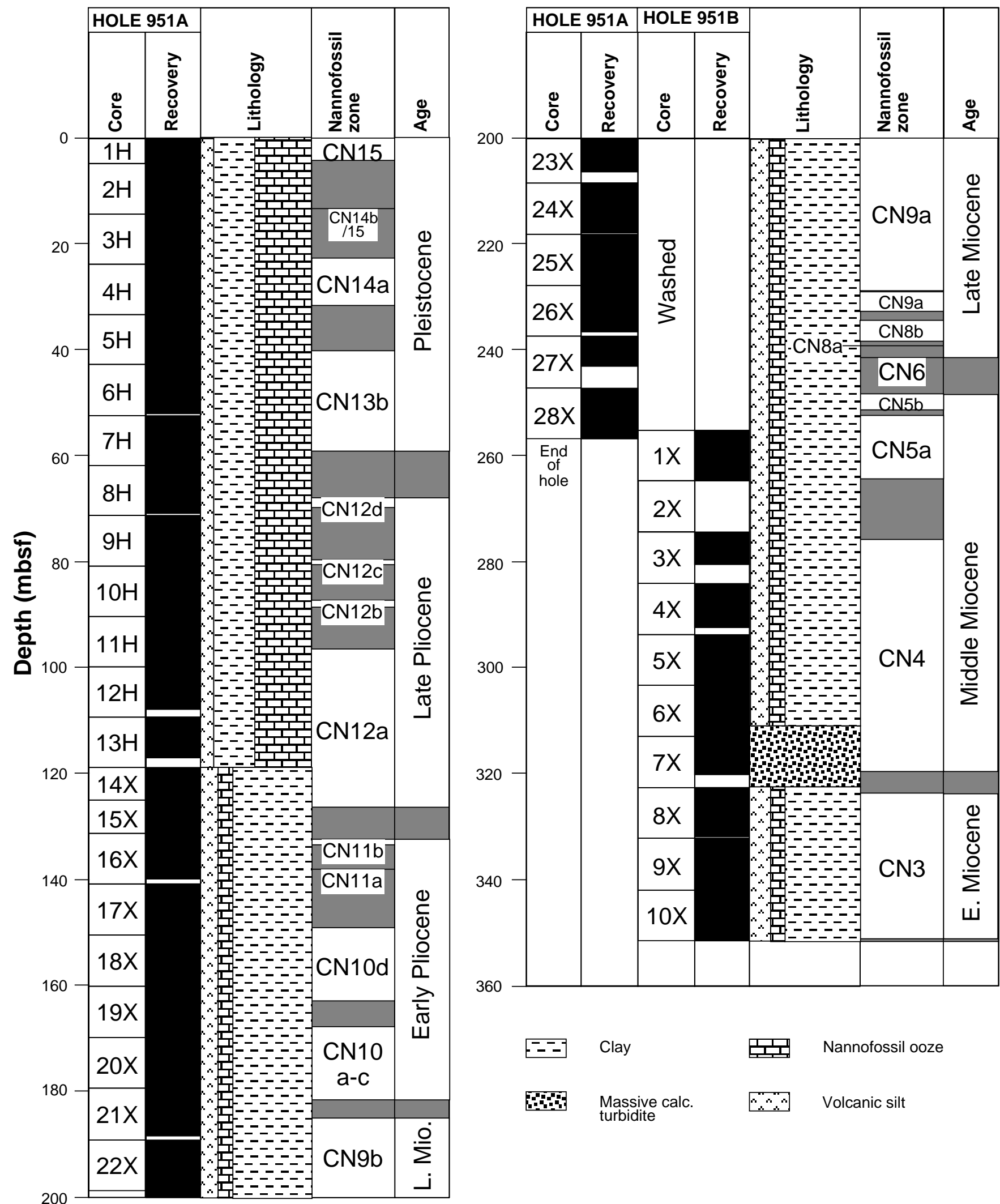

Figure 3. Composite nannofossil zonation and schematic lithology of Holes 951A and 951B. Pliocene-Quaternary data are from Schmincke, Weaver, Firth, et al. (1995). 
157-950A-27X-3, $111 \mathrm{~cm}$ (241.30 mbsf), which contained C. coalitus.

\section{Middle Miocene}

The top of Subzone CN5b occurs in Sample 157-951A-28X-1, $119 \mathrm{~cm}$ (248.04 mbsf), with the base being marked by the LO of Discoaster kugleri in Sample 157-951A-28X-3, $138 \mathrm{~cm}$ (251.17 mbsf). Subzone CN5a has its top in Sample 157-951A-28X-4, $91 \mathrm{~cm}$ (252.18 mbsf). As at Site 950, the base of CN5a is approximated by the LO of Triquetrorhabdulus rugosus in Sample 157-951B-1X-6, $68.5 \mathrm{~cm}$ (262.96 mbsf). Zone CN4 has its top in Sample 157-951B$1 \mathrm{X}-6,94 \mathrm{~cm}(263.21 \mathrm{mbsf})$. The base of the zone is approximated by the LO of D. signus, which occurs in Sample 157-951B-7X-5, $59 \mathrm{~cm}$ (319.39 mbsf), at the base of the Cruiser turbidite, which at this site, occurs between Sections 157-951B-7X-3, $55 \mathrm{~cm}$ (316.35 mbsf), and 7X-CC, $17 \mathrm{~cm}$ (319.97 mbsf).

\section{Early Miocene}

The preservation and abundance of nannofossils in early Miocene sediments is similar to that in the middle and late Miocene, in contrast to Site 950 where preservation was poor. The top of Zone CN3 occurs in Sample 157-951B-8X-1, $107 \mathrm{~cm}$ (323.41 mbsf), with the base of the zone not observed. The deepest sample examined was Sample 157-951B-10X-CC, $23 \mathrm{~cm}$ (351.07 mbsf), which contains D. exilis and $S$. heteromorphus and belongs to the upper part of Zone CN3. Similarly to Site 950, biogenic siliceous debris is present in Zones CN3 and 4, between Samples 157-951B-3X-1, $138 \mathrm{~cm}$ (275.09 mbsf), and 10X-CC, $23 \mathrm{~cm}$ (351.07 mbsf).

\section{Site 952}

Site 952 lies in the southeastern part of the MAP at $30^{\circ} 47.449^{\prime} \mathrm{N}$, $24^{\circ} 30.574^{\prime} \mathrm{W}$, at a water depth of $5431.8 \mathrm{~m}$ in the Cruiser Fracture Zone Valley (see Searle, 1987). Hole 952A penetrated $425.24 \mathrm{~m}$ of early Miocene to Holocene sediment from 15 APC cores (0-142.8 mbsf) and 30 XCB cores (142.8-425.24 mbsf), with $97.5 \%$ recovery (Shipboard Scientific Party, 1995c). The distribution and biostratigraphy of nannofossils from Hole 952A is shown in Table 4 (backpocket foldout, this volume), and the biostratigraphy is summarized in Figure 4.

\section{Late Miocene}

The overall Miocene sequence at Site 952 is very similar to that at Site 951 and to the middle and late Miocene sequence at Site 950. Nannofossil abundance in turbidites varies from moderate to high, and preservation is generally moderate to good throughout. Pelagic clays examined are mostly barren, with a few having very low to low abundances of poorly preserved nannofossils. The top of the Miocene occurs in Sample 157-950A-20X-4, $139 \mathrm{~cm}$ (180.68 mbsf), where the $\mathrm{HO}$ of $D$. quinqueramus marks the top of Subzone CN9b. The sequence of significant secondary events in CN9b at Site 952 is similar to that of other two sites. The HO's of A. amplificus and $R$. rotaria occur together in Sample 157-952A-21X-1, $93 \mathrm{~cm}$ (185.40 mbsf). The LO of A. amplificus occurs in Sample 157-952A-23X-5, $10 \mathrm{~cm}$ (209.75 mbsf), with the reappearance of large R. pseudoumbilicus occurring in Sample 157-952A-24X-2, $14.5 \mathrm{~cm}$ (215.02 mbsf). The LO of A. delicatus occurs in Sample 157-952A-24X-2, $59 \mathrm{~cm}(215.46$ mbsf), with $R$. rotaria having its LO in Sample 24X-5, $69 \mathrm{~cm}(219.98$ mbsf). The base of Subzone CN9b is marked in Sample 157-952A25X-CC, $26 \mathrm{~cm}$ (231.01 mbsf), by the LO of A. primus. The top of Subzone CN9a occurs in Sample 157-952A-26X-1, 58 cm (233.18 mbsf). The LO of D. quinqueramus in Sample 157-952A-26X-3, 96 $\mathrm{cm}$ (236.53 mbsf), marks the base of CN9a.

The top of Subzone CN8b occurs in Sample 157-952A-27X-1, $144.5 \mathrm{~cm}$ (243.68 mbsf), with the base of the zone occurring in Sample $27 \mathrm{X}-4,128 \mathrm{~cm}$ (248.01 mbsf). The top of Subzone CN8a is approximated by the temporary $\mathrm{HO}$ of large $R$. pseudoumbilicus in Sample 157-27X-CC, $5 \mathrm{~cm}$ (249.77 mbsf). The base of CN8a is approximated by the LO of D. pentaradiatus in Sample 157-952A$28 \mathrm{X}-1,113.5 \mathrm{~cm}(252.97 \mathrm{mbsf})$. The LO of M. convallis occurs in the same sample. The top of Zone CN7 occurs in Sample 157-952A$28 \mathrm{X}-3,11.5 \mathrm{~cm}$ (254.92 mbsf), with the base of the zone marked in Sample 157-952A-28X-3, $97 \mathrm{~cm}$ (255.78 mbsf), by the LO of $D$. hamatus. Only two samples examined belonged to Zone CN6, Sample 157-952A-29X-1, $110.5 \mathrm{~cm}$ (262.69 mbsf), and Sample 29X-3, $53 \mathrm{~cm}$ (265.07 mbsf), in which the LO of C. coalitus occurs.

\section{Middle Miocene}

Subzone CN5b extends from Sample 157-952A-29X-4, $8 \mathrm{~cm}$ (266.11 mbsf), to Sample 30X-2, $145 \mathrm{~cm}$ (274.19 mbsf), where its base is marked by the LO of D. kugleri. The top of Subzone CN5a occurs in Sample 157-952A-30X-4, $122 \mathrm{~cm}$ (276.91 mbsf). The LO of T. rugosus in Sample 157-952A-31X-3, $26 \mathrm{~cm}$ (284.17 mbsf), approximates the base of $\mathrm{CN} 5 \mathrm{a}$, as the zonal marker $S$. heteromorphus is clearly reworked above this level. The Cruiser turbidite occurs in Hole 952A between Sections 157-952A-40X-4, $114 \mathrm{~cm}$ (373.56 mbsf), and 40X-7, $56 \mathrm{~cm}$ (377.48 mbsf), and as in the other two sites, the base of Zone CN4 occurs at its base, with the LO of D. signus in Sample 40X-5, $32 \mathrm{~cm}$ (374.24 mbsf). The top of CN4 occurs in Sample 157-952A-31X-6, $28 \mathrm{~cm}$ (288.65 mbsf).

\section{Early Miocene}

As at Site 951, the base of Zone CN3 was not observed at Site 952. The deepest sample examined from Site 952 is Sample 157-952A45X-6, $25 \mathrm{~cm}$ (423.90 mbsf). This sample contains $D$. exilis and $S$. heteromorphus and belongs to the upper part of Zone CN3. The top of CN3 occurs in Sample 157-952A-40X-6, $99 \mathrm{~cm}$ (376.41 mbsf). Similarly to the other two sites, biogenic siliceous debris is present in Zones CN3 and 4, between Samples 157-952A-31X-3, $26 \mathrm{~cm}$ (284.17 mbsf), and 45X-6, $25 \mathrm{~cm}$ (423.90 mbsf).

\section{SEDIMENT ACCUMULATION RATES}

Two age-depth plots with visual best-fit sediment accumulation rate curves have been constructed for each site: one for the total sediment thickness, and one for the pelagic sediment thickness from which the thickness of all turbidites has been subtracted. The pelagic age-depth plots were constructed to indicate background sediment accumulation rates and to give an indication of major changes in the CCD that have affected carbonate preservation (see Weaver et al., Chap. 38, this volume). During intervals when the CCD is lowered, calcareous pelagic sediments accumulate at higher rates than the red clays, which are deposited during intervals when the CCD is raised. The effects of compaction are not accounted for here, so the calculated accumulation rates in the deeper part of each section should be regarded as minimum values.

Sediment accumulation rates for Site 950 are based on eight paleomagnetic and 43 nannofossil-aged estimates (Table 5). For Site 951, they are based on five paleomagnetic and 32 nannofossil-aged estimates (Table 6), and for Site 952, they are based on six paleomagnetic and 31 nannofossil-aged estimates (Table 7). Paleomagnetic and Pliocene-Quaternary nannofossil-aged estimates are taken from Schmincke, Weaver, Firth, et al. (1995). 

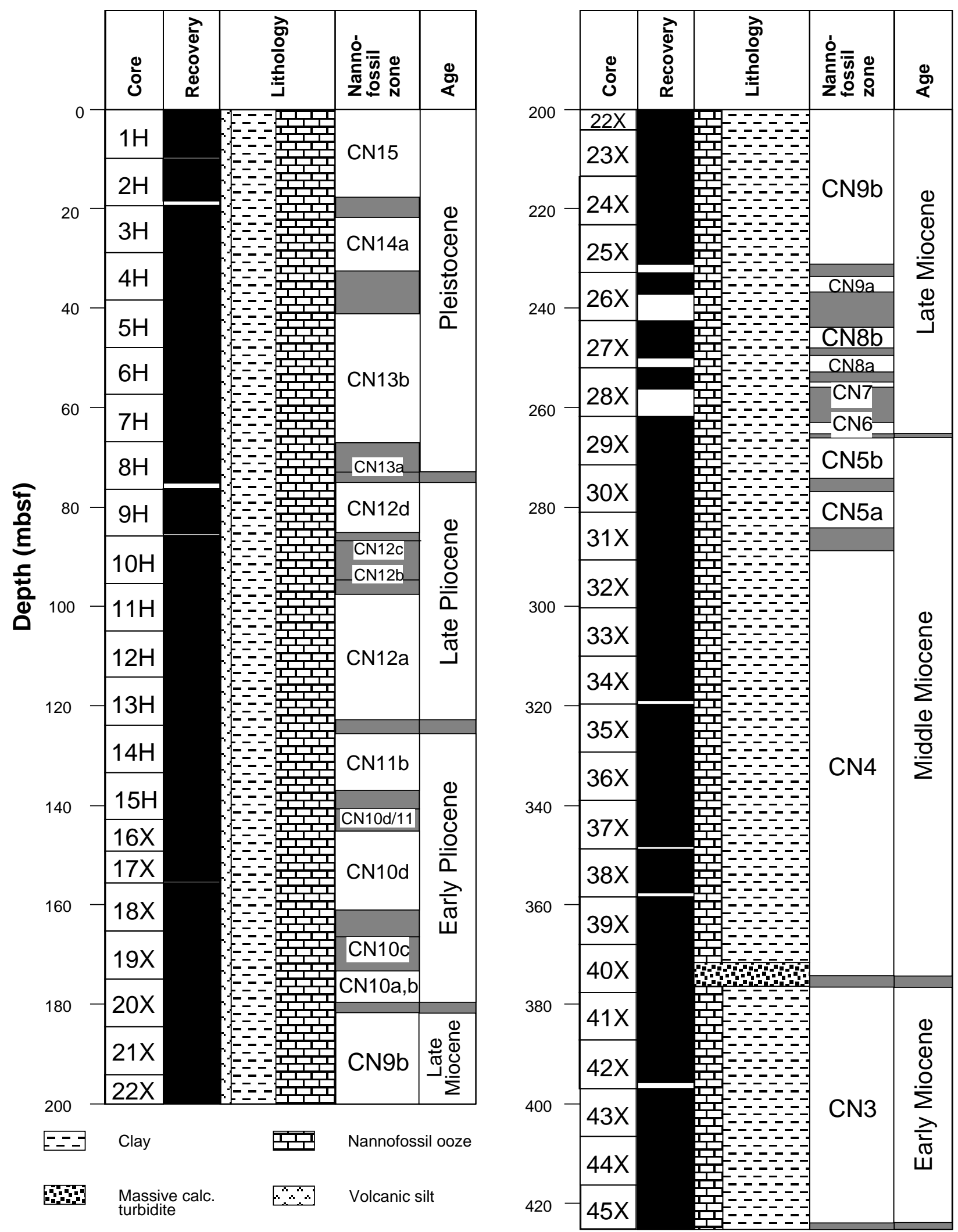

Figure 4. Nannofossil zonation and schematic lithology of Hole 952A. Pliocene-Quaternary data are from Schmincke, Weaver, Firth, et al. (1995). 
Table 5. Nannofossil and paleomagnetic datums used in construction of age-depth and pelagic age-thickness plots, Hole 950A.

\begin{tabular}{|c|c|c|c|c|c|c|c|c|}
\hline & \multirow[b]{2}{*}{ Event } & \multicolumn{2}{|c|}{ Core, section, interval } & \multicolumn{2}{|c|}{ Depth } & \multicolumn{2}{|c|}{ Pelagic thickness (m) } & \multirow{2}{*}{$\begin{array}{l}\text { Age } \\
(\mathrm{Ma})\end{array}$} \\
\hline & & Top $(\mathrm{cm})$ & Bottom $(\mathrm{cm})$ & Top (mbsf) & Bottom (mbsf) & Top & Bottom & \\
\hline 1 & LO E. huxleyi & $950 \mathrm{~A}-2 \mathrm{H}-7,20.5$ & $950 \mathrm{~A}-3 \mathrm{H}-7,78$ & 17.89 & 26.80 & 1.02 & 2.67 & 0.26 \\
\hline 2 & HO P. lacunosa & $950 \mathrm{~A}-2 \mathrm{H}-7,20.5$ & $950 \mathrm{~A}-3 \mathrm{H}-7,78$ & 17.89 & 26.80 & 1.02 & 2.67 & 0.46 \\
\hline 3 & Brunhes/Matuyama boundary & $950 \mathrm{~A}-4 \mathrm{H}-6,20-40$ & - & 35.42 & - & 3.31 & - & 0.78 \\
\hline 4 & HO R. asanoi & $950 \mathrm{~A}-4 \mathrm{H}-6,110.5$ & 950A-4H-CC, 12 & 36.30 & 37.28 & 3.53 & 3.93 & 0.83 \\
\hline 5 & Jaramillo Top & $950 \mathrm{~A}-6 \mathrm{H}-1,55-70$ & - & 47.44 & - & 5.08 & - & 0.98 \\
\hline 6 & Jaramillo Bottom & $950 \mathrm{~A}-6 \mathrm{H}-6,80-145$ & - & 54.85 & - & 6.58 & - & 1.05 \\
\hline 7 & LO $R$. asanoi & $950 \mathrm{~A}-5 \mathrm{H}-5,2$ & $950 \mathrm{~A}-6 \mathrm{H}-6,90$ & 43.19 & 54.95 & 5.08 & 6.67 & 1.06 \\
\hline 8 & Olduvai Top & $950 \mathrm{~A}-8 \mathrm{H}-3,20$ & - & 68.64 & - & 9.35 & - & 1.76 \\
\hline 9 & LO G. carribeanica & $950 \mathrm{~A}-8 \mathrm{H}-6,109$ & $950 \mathrm{~A}-9 \mathrm{H}-3,70$ & 74.02 & 79.03 & 10.09 & 11.73 & 1.80 \\
\hline 10 & HO D. brouweri & $950 \mathrm{~A}-8 \mathrm{H}-6,109$ & $950 \mathrm{~A}-9 \mathrm{H}-3,70$ & 74.02 & 79.03 & 10.09 & 11.73 & 1.95 \\
\hline 11 & Olduvai Bottom & $950 \mathrm{~A}-9 \mathrm{H}-2,80$ & - & 77.66 & - & 11.00 & - & 1.98 \\
\hline 12 & HO D. pentaradiatus & 950A-9H-6, 12 & $950 \mathrm{~A}-10 \mathrm{H}-5,59$ & 82.88 & 89.91 & 12.07 & 13.32 & 2.44 \\
\hline 13 & Gauss/Matuyama boundary & $950 \mathrm{~A}-12 \mathrm{H}-1,15$ & - & 104.05 & - & 14.58 & - & 2.60 \\
\hline 14 & HO D. tamalis & $950 \mathrm{~A}-10 \mathrm{H}-6,17$ & $950 \mathrm{~A}-11 \mathrm{H}-5,96$ & 90.99 & 101.24 & 13.58 & 14.24 & 2.76 \\
\hline 15 & Kaena Top & $950 \mathrm{~A}-14 \mathrm{H}-2,140$ & - & 125.80 & - & 15.32 & - & 3.04 \\
\hline 16 & Kaena Bottom & $950 \mathrm{~A}-14 \mathrm{H}-6,60$ & - & 131.00 & - & 15.44 & - & 3.11 \\
\hline 17 & HO R. pseudoumbilicus & $950 \mathrm{~A}-15 \mathrm{H}-5,130$ & $950 \mathrm{~A}-16 \mathrm{H}-6,80$ & 139.70 & 149.92 & 16.00 & 16.50 & 3.77 \\
\hline 18 & HO A. delicatus & $950 \mathrm{~A}-17 \mathrm{X}-4,21$ & $950 \mathrm{~A}-18 \mathrm{X}-2,133.5$ & 153.83 & 156.36 & 16.62 & 16.65 & 4.39 \\
\hline 19 & LO D. asymmetricus & $950 \mathrm{~A}-18 \mathrm{X}-2,133.5$ & $950 \mathrm{~A}-18 \mathrm{X}-\mathrm{CC}, 49$ & 156.36 & 157.39 & 16.65 & 16.70 & 4.79 \\
\hline 20 & LO C. acutus & 950A-20X-CC, 33 & $950 \mathrm{~A}-21 \mathrm{X}-5,23.5$ & 178.35 & 184.64 & 17.59 & 17.96 & 5.34 \\
\hline 21 & HO D. quinqueramus & $950 \mathrm{~A}-21 \mathrm{X}-5,23.5$ & $950 \mathrm{~A}-21 \mathrm{X}-5,108$ & 184.64 & 185.49 & 17.96 & 18.21 & 5.4 \\
\hline 22 & HO A. amplificus & $950 \mathrm{~A}-22 \mathrm{X}-6,82$ & $950 \mathrm{~A}-23 \mathrm{X}-1,90$ & 196.29 & 198.70 & 18.85 & 18.85 & 5.8 \\
\hline 23 & HO $R$. rotaria & $950 \mathrm{~A}-22 \mathrm{X}-6,82$ & $950 \mathrm{~A}-23 \mathrm{X}-1,90$ & 196.29 & 198.70 & 18.85 & 18.85 & 6.1 \\
\hline 24 & LO A. amplificus & $950 \mathrm{~A}-25 \mathrm{X}-1,41.5$ & $950 \mathrm{~A}-25 \mathrm{X}-2,114$ & 217.54 & 219.76 & 19.82 & 20.11 & 6.5 \\
\hline 25 & LO $R$. pseudoumbilicus $>7 \mu \mathrm{m}$ & $950 \mathrm{~A}-25 \mathrm{X}-3,49$ & 950A-25X-6, 97 & 220.61 & 225.59 & 20.11 & 20.23 & 6.6 \\
\hline 26 & LO A. delicatus & $950 \mathrm{~A}-26 \mathrm{X}-3,107$ & $950 \mathrm{~A}-26 \mathrm{X}-4,14$ & 230.79 & 231.36 & 20.49 & 20.51 & 6.8 \\
\hline 27 & LO $R$. rotaria & $950 \mathrm{~A}-26 \mathrm{X}-4,14$ & $950 \mathrm{~A}-26-4,94$ & 231.36 & 232.16 & 20.51 & 20.88 & 6.9 \\
\hline 28 & LO A. primus & 950A-26X-4, 94 & $950 \mathrm{~A}-26 \mathrm{X}-5,95.5$ & 232.16 & 233.68 & 20.88 & 21.23 & 7.2 \\
\hline 29 & HO $M$. convallis & $950 \mathrm{~A}-26 \mathrm{X}-4,14$ & $950 \mathrm{~A}-26 \mathrm{X}-4,94$ & 231.36 & 232.16 & 20.51 & 20.88 & 7.5 \\
\hline 30 & LO D. quinqueramus & $950 \mathrm{~A}-27 \mathrm{X}-3,23$ & $950 \mathrm{~A}-27 \mathrm{X}-4,70$ & 239.63 & 241.54 & 21.74 & 22.01 & 8.2 \\
\hline 31 & HO R. pseudoumbilicus $>7 \mu \mathrm{m}$ & $950 \mathrm{~A}-28 \mathrm{X}-1,32$ & $950 \mathrm{~A}-28 \mathrm{X}-2,65.5$ & 246.32 & 248.16 & 22.54 & 22.64 & 8.6 \\
\hline 32 & LO M. convallis & $950 \mathrm{~A}-28 \mathrm{X}-2,147$ & $950 \mathrm{~A}-28 \mathrm{X}-3,36$ & 248.97 & 249.36 & 22.75 & 22.81 & 9.7 \\
\hline 33 & LO D. neohamatus & $950 \mathrm{~A}-28 \mathrm{X}-2,147$ & $950 \mathrm{~A}-28 \mathrm{X}-3,36$ & 248.97 & 249.36 & 22.75 & 22.81 & 9.8 \\
\hline 34 & LO D. hamatus & $950 \mathrm{~A}-28 \mathrm{X}-\mathrm{CC}, 32$ & $950 \mathrm{~A}-29 \mathrm{X}-2,29.5$ & 249.88 & 257.50 & 22.83 & 23.06 & 10.4 \\
\hline 35 & LO C. coalitus & $950 \mathrm{~A}-29 \mathrm{X}-4,41$ & $950 \mathrm{~A}-29 \mathrm{X}-6,53$ & 260.60 & 263.73 & 23.25 & 23.63 & 10.6 \\
\hline 36 & LO D. kugleri & $950 \mathrm{~A}-30 \mathrm{X}-5,85$ & $950 \mathrm{~A}-30 \mathrm{X}-6,95$ & 272.22 & 273.82 & 24.07 & 24.11 & 12.0 \\
\hline 37 & LO T. rugosus & $950 \mathrm{~A}-32 \mathrm{X}-2,30$ & $950 \mathrm{~A}-32 \mathrm{X}-6,19$ & 286.57 & 292.38 & 24.59 & 24.83 & 13.0 \\
\hline 38 & LO D. signus & $950 \mathrm{~A}-34 \mathrm{X}-2,50.5$ & $950 \mathrm{~A}-35 \mathrm{X}-1,53$ & 306.00 & 314.13 & 25.59 & 25.59 & 16.0 \\
\hline 39 & LO D. exilis & $950 \mathrm{~A}-36 \mathrm{X}-1,55$ & $950 \mathrm{~A}-36 \mathrm{X}-2,7$ & 323.68 & 324.60 & 25.83 & 26.17 & 17.0 \\
\hline 40 & LO $S$. heteromorphus & $950 \mathrm{~A}-36 \mathrm{X}-2,7$ & $950 \mathrm{~A}-36 \mathrm{X}-2,109$ & 324.60 & 325.62 & 26.17 & 26.83 & 18.2 \\
\hline 41 & LO S. belemnos & 950A-36X-CC, 25 & $950 \mathrm{~A}-37 \mathrm{X}-2,65.5$ & 326.29 & 335.09 & 26.83 & 28.62 & 19.2 \\
\hline 42 & HO D. bisectus & $950 \mathrm{~A}-36 \mathrm{X}-\mathrm{CC}, 25$ & $950 \mathrm{~A}-37 \mathrm{X}-2,65.5$ & 326.29 & 335.09 & 26.83 & 28.62 & 23.7 \\
\hline 43 & HO S. ciperoensis & $950 \mathrm{~A}-36 \mathrm{X}-\mathrm{CC}, 25$ & $950 \mathrm{~A}-37 \mathrm{X}-2,65.5$ & 326.29 & 335.09 & 26.83 & 28.62 & 24.6 \\
\hline 44 & HO S. distentus & $950 \mathrm{~A}-37 \mathrm{X}-3,122$ & $950 \mathrm{~A}-37 \mathrm{X}-4,128.5$ & 337.10 & 338.62 & 29.99 & 30.93 & 27.0 \\
\hline 45 & LO S. ciperoensis & $950 \mathrm{~A}-37 \mathrm{X}-7,9$ & $950 \mathrm{~A}-37 \mathrm{X}-\mathrm{CC}, 45$ & 341.83 & 342.59 & 33.38 & 33.91 & 28.6 \\
\hline 46 & LO S. distentus & $950 \mathrm{~A}-38 \mathrm{X}-2,115$ & $950 \mathrm{~A}-38 \mathrm{X}-3,112$ & 345.21 & 346.65 & 36.52 & 37.92 & 32.1 \\
\hline 47 & HO R. umbilicus & $950 \mathrm{~A}-38 \mathrm{X}-6,46$ & $950 \mathrm{~A}-38 \mathrm{X}-6,131$ & 350.42 & 351.25 & 40.99 & 41.73 & 32.4 \\
\hline 48 & HO C. formosus & $950 \mathrm{~A}-38 \mathrm{X}-\mathrm{CC}, 42$ & $950 \mathrm{~A}-39 \mathrm{X}-1,89$ & 352.29 & 353.18 & 42.73 & 43.57 & 32.9 \\
\hline 49 & HO D. saipanensis & $950 A-39 X-5,29$ & $950 \mathrm{~A}-39 \mathrm{X}-6,130$ & 358.44 & 360.93 & 48.33 & 50.45 & 34.2 \\
\hline 50 & LO I. recurvus & $950 \mathrm{~A}-40 \mathrm{X}-3,38$ & $950 \mathrm{~A}-40 \mathrm{X}-3,130$ & 365.38 & 366.30 & 54.36 & 54.84 & 36.2 \\
\hline 51 & absence $C$. grandis & $950 \mathrm{~A}-40 \mathrm{X}-4,17$ & - & 366.67 & - & 55.13 & - & $<37.1$ \\
\hline
\end{tabular}

Note: Pliocene-Quaternary datums are from Schmincke, Weaver, Firth, et al. (1995), with the ages assigned to them taken from Curry, Shackleton, Richter, et al. (1995).

\section{Site 950}

\section{Pelagic Sediment Accumulation Rates}

Between 0 and 2.7 Ma (late Pliocene-Quaternary), the accumulation rate of pelagic sediment was $4.8 \mathrm{~m} / \mathrm{m}$.y. (Fig. 5), which is close to the typical pelagic accumulation rates of 5-6 m/m.y. on the slope of the west African margin (Weaver, 1994). From 2.7 to $8.3 \mathrm{Ma}$ (late Miocene/early Pliocene,), the rate decreased sharply to $1.4 \mathrm{~m} / \mathrm{m} . \mathrm{y}$, and from 8.3 Ma to the 17.1-Ma hiatus (late-early to early-late Miocene), the rate decreased further to $0.6 \mathrm{~m} / \mathrm{m}$.y. The higher rate from 0 to $2.7 \mathrm{Ma}$ is approximately coincident with a gradual uphole change in pelagic sediment type from red clays with occasional marly intervals to alternating clays, marls, and oozes. It also coincides with the onset of Northern Hemisphere glaciation, which occurred between 2.5 and 3.0 Ma (Raymo, 1994) and was accompanied by a sharp depression of the CCD. The lower rates from 2.7 to 8.3 Ma reflect a lower calcareous component in the pelagic sediment, with the rate from 8.3 to 17.1 Ma probably reflecting the accumulation rate of red clays with no calcareous component.

Below the disconformity at $26.5 \mathrm{Ma}$, the pelagic sediment consists of red clays with occasional volcanic ash layers, presumably derived from the volcanoes of the Great Meteor Seamount Chain, which were active during this time (Tucholke and Smoot, 1990). These ash layers and disseminated volcaniclastic debris in the red clays (Shipboard Scientific Party, 1995a) caused higher pelagic accumulation rates of $1.6 \mathrm{~m} / \mathrm{m}$.y. between 26.5 and $32.0 \mathrm{Ma}$ (Oligocene), and 5.3 $\mathrm{m} / \mathrm{m}$.y. between 32.0 and $34.4 \mathrm{Ma}$ (earliest Oligocene). In the oldest section penetrated at the site, from 34.4 to $37.1 \mathrm{Ma}$ (late Eocene), the rate decreased to $1.9 \mathrm{~m} / \mathrm{m}$.y. The high rate between 32.0 and $34.4 \mathrm{Ma}$ perhaps reflects a period of increased volcanic activity in the seamount chain, whereas the lower rates above the disconformity suggest that this volcanic activity ceased sometime during the interval of missing time (17.1-26.5 Ma, during which a single turbidite but no pelagic sediments were deposited).

\section{Total Sediment Accumulation Rates}

The total accumulation rate from 0 to $2.9 \mathrm{Ma}$ (late Pliocene-Quaternary) is $39 \mathrm{~m} / \mathrm{m} . y$. (Fig. 6), a high rate which reflects frequent emplacement of turbidites onto the MAP and also high pelagic accumulation during interglacial intervals. From 2.9 to $6.5 \mathrm{Ma}$ (latest Miocene to early late Pliocene), the rate is $24 \mathrm{~m} / \mathrm{m}$.y., a lower rate at least partially because of a substantially lower pelagic accumulation during this interval (see above). From 6.5 to 9.9 Ma (late Miocene), the 
Table 6. Nannofossil and paleomagnetic datums used in construction of age-depth and pelagic age-thickness plots, Holes 951A and 951B.

\begin{tabular}{|c|c|c|c|c|c|c|c|c|}
\hline & \multirow[b]{2}{*}{ Event } & \multicolumn{2}{|c|}{ Core, section, interval } & \multicolumn{2}{|c|}{ Depth } & \multicolumn{2}{|c|}{ Pelagic thickness (m) } & \multirow{2}{*}{$\begin{array}{l}\text { Age } \\
\text { (Ma) }\end{array}$} \\
\hline & & Top (cm) & Bottom (cm) & Top (mbsf) & Bottom (mbsf) & Top & Bottom & \\
\hline 1 & HO P. lacunosa & $951 \mathrm{~A}-3 \mathrm{H}-7,8$ & $951 \mathrm{~A}-4 \mathrm{H}-4,18$ & 22.15 & 28.48 & 2.31 & 2.73 & 0.46 \\
\hline 2 & Brunhes/Matuyama boundary & $951 \mathrm{~A}-4 \mathrm{H}-3,15$ & - & 26.95 & - & 2.57 & - & 0.78 \\
\hline 3 & HO R. asanoi & $951 \mathrm{~A}-4 \mathrm{H}-4,18$ & $951 \mathrm{~A}-4 \mathrm{H}-6,18$ & 28.48 & 31.48 & 2.73 & 3.09 & 0.83 \\
\hline 4 & Jaramillo Top & $951 \mathrm{~A}-5 \mathrm{H}-4,50-65$ & - & 38.10 & - & 3.71 & - & 0.99 \\
\hline 5 & LO R. asanoi & $951 \mathrm{~A}-4 \mathrm{H}-6,18$ & $951 \mathrm{~A}-5 \mathrm{H}-5,72$ & 31.48 & 39.79 & 3.09 & 3.95 & 1.06 \\
\hline 6 & LO G. oceanica & $951 \mathrm{~A}-4 \mathrm{H}-6,18$ & $951 \mathrm{~A}-5 \mathrm{H}-5,72$ & 31.48 & 39.79 & 3.09 & 3.95 & 1.08 \\
\hline 7 & HO Gephyrocapsa spp. $>4 \mu \mathrm{m}$ & $951 \mathrm{~A}-5 \mathrm{H}-6,84.5$ & $951 \mathrm{~A}-6 \mathrm{H}-4,5$ & 41.38 & 47.24 & 3.97 & 5.46 & 1.24 \\
\hline 9 & LO G. caribbeanica & $951 \mathrm{~A}-7 \mathrm{H}-5,63$ & $951 \mathrm{~A}-8 \mathrm{H}-5,45.5$ & 58.68 & 67.75 & 7.35 & 9.18 & 1.80 \\
\hline 10 & HO D. brouweri & $951 \mathrm{~A}-7 \mathrm{H}-5,63$ & $951 \mathrm{~A}-8 \mathrm{H}-5,45.5$ & 58.68 & 67.75 & 7.35 & 9.18 & 1.95 \\
\hline 11 & Olduvai Bottom & $951 \mathrm{~A}-8 \mathrm{H}-4,90$ & - & 66.69 & - & 8.94 & - & 1.95 \\
\hline 12 & LO D.triradiatus acme & $951 \mathrm{~A}-8 \mathrm{H}-6,81$ & 951A-9H-6, 62 & 69.60 & 79.31 & 9.73 & 10.96 & 2.15 \\
\hline 13 & Gauss Top & $951 \mathrm{~A}-10 \mathrm{H}-5,40$ & $951 \mathrm{~A}-12 \mathrm{H}-1,15$ & 87.07 & 99.95 & 11.42 & 11.96 & 2.60 \\
\hline 14 & HO D. surculus & $951 \mathrm{~A}-9 \mathrm{H}-7,7.5$ & $951 \mathrm{~A}-10 \mathrm{H}-5,37$ & 80.21 & 87.04 & 11.22 & 11.39 & 2.61 \\
\hline 15 & HO D. tamalis & $951 \mathrm{~A}-10 \mathrm{H}-6,16$ & $951 \mathrm{~A}-11 \mathrm{H}-4,148$ & 88.33 & 96.06 & 11.44 & 11.79 & 2.76 \\
\hline 16 & HO R.pseudoumbilicus & $951 \mathrm{~A}-15 \mathrm{X}-1,119$ & $951 \mathrm{~A}-15 \mathrm{X}-\mathrm{CC}, 5$ & 125.96 & 131.04 & 12.76 & 13.48 & 3.77 \\
\hline 17 & LO D. tamalis & $951 \mathrm{~A}-16 \mathrm{X}-2,53.5$ & $951 \mathrm{~A}-16 \mathrm{X}-5,64$ & 133.00 & 137.08 & 13.80 & 14.02 & 4.01 \\
\hline 18 & HO Amaurolithus spp. & 951A-16X-5, 64 & 951A-17X-6, 60 & 137.08 & 148.88 & 14.02 & 15.02 & 4.39 \\
\hline 21 & HO A. amplificus & 951A-21X-CC, 1 & $951 \mathrm{~A}-22 \mathrm{X}-4,35$ & 187.83 & 193.80 & 17.27 & 17.52 & 5.8 \\
\hline 22 & HO $R$. rotaria & $951 \mathrm{~A}-21 \mathrm{X}-\mathrm{CC}, 1$ & $951 \mathrm{~A}-22 \mathrm{X}-4,35$ & 187.83 & 193.80 & 17.27 & 17.52 & 6.1 \\
\hline 23 & LO A. amplificus & $951 \mathrm{~A}-24 \mathrm{X}-6,102$ & $951 \mathrm{~A}-24 \mathrm{X}-\mathrm{CC}, 17.5$ & 216.82 & 217.47 & 18.73 & 18.90 & 6.5 \\
\hline 24 & LO R. pseudoumbilicus $>7 \mu \mathrm{m}$ & 951A-24X-6, 102 & 951A-24X-CC, 17.5 & 216.82 & 217.47 & 18.73 & 18.90 & 6.6 \\
\hline 25 & LO A. delicatus & $951 \mathrm{~A}-25 \mathrm{X}-1,91$ & $951 \mathrm{~A}-25 \mathrm{X}-2,105$ & 218.87 & 220.47 & 19.09 & 19.20 & 6.8 \\
\hline 26 & LO $R$. rotaria & $951 \mathrm{~A}-25 \mathrm{X}-\mathrm{CC}, 20$ & $951 \mathrm{~A}-25 \mathrm{X}-\mathrm{CC}, 27$ & 227.45 & 227.52 & 19.46 & 19.46 & 6.9 \\
\hline 27 & HO $M$. convallis & $951 \mathrm{~A}-25 \mathrm{X}-\mathrm{CC}, 27$ & $951 \mathrm{~A}-26 \mathrm{X}-1,105$ & 227.52 & 228.67 & 19.46 & 19.79 & 7.5 \\
\hline 28 & LO D. quinqueramus & $951 \mathrm{~A}-26 \mathrm{X}-4,56$ & $951 \mathrm{~A}-26 \mathrm{X}-5,71$ & 232.66 & 234.31 & 20.37 & 20.79 & 8.2 \\
\hline 29 & HO R. pseudoumbilicus $>7 \mu \mathrm{m}$ & 951A-26X-6, 27 & 951A-27X-1, 97 & 235.37 & 238.16 & 21.00 & 21.24 & 8.6 \\
\hline 30 & LO M. convallis & $951 \mathrm{~A}-27 \mathrm{X}-2,32$ & $951 \mathrm{~A}-27 \mathrm{X}-3,111$ & 239.01 & 241.30 & 21.34 & 21.66 & 9.7 \\
\hline 31 & LO D. neohamatus & $951 \mathrm{~A}-27 \mathrm{X}-2,32$ & 951A-27X-3, 111 & 239.01 & 241.30 & 21.34 & 21.66 & 9.8 \\
\hline 32 & LO C. coalitus & $951 \mathrm{~A}-27 \mathrm{X}-3,111$ & $951 \mathrm{~A}-28 \mathrm{X}-1,119$ & 241.30 & 248.04 & 21.66 & 22.08 & 10.6 \\
\hline 33 & LO D. kugleri & $951 \mathrm{~A}-28 \mathrm{X}-3,138$ & $951 \mathrm{~B}-28 \mathrm{X}-4,91$ & 251.17 & 252.18 & 22.77 & 22.81 & 12.0 \\
\hline 34 & LO T. rugosus & $951 \mathrm{~B}-1 \mathrm{X}-6,68.5$ & 951B-1X-CC, 7 & 262.96 & 264.31 & 23.05 & 23.07 & 13.0 \\
\hline 35 & LO R. pseudoumbilicus $>7 \mu \mathrm{m}$ & 951B-1X-CC, 7 & $951 \mathrm{~B}-3 \mathrm{X}-1,138$ & 264.31 & 275.09 & 23.07 & 23.24 & 13.1 \\
\hline 36 & LO D. signus & 951B-7X-5, 59 & 951B-8X-1, 107 & 319.39 & 323.41 & 24.21 & 24.24 & 16.0 \\
\hline 37 & LO D. exilis & 951B-10X-CC, 23 & - & 351.07 & - & 24.93 & - & $\leq 17.0$ \\
\hline
\end{tabular}

Note: Pliocene-Quaternary datums are from Schmincke, Weaver, Firth, et al. (1995), with the ages assigned to them taken from Curry, Shackleton, Richter, et al. (1995).

rate is lower again at $10.4 \mathrm{~m} / \mathrm{m} . \mathrm{y}$. , and from 9.9 to $17.1 \mathrm{Ma}$ (late early to early late Miocene), the rate decreases further to $8.0 \mathrm{~m} / \mathrm{m}$.y. These lower rates presumably reflect the combination of low pelagic accumulation rates and the effects of compaction. Also volcanic turbidites derived from the Canary Islands do not occur with any significant frequency below $\sim 7 \mathrm{Ma}$, whereas calcareous and organic turbidites occur with approximately constant frequency during the interval from 0 to $17.1 \mathrm{Ma}$ (see Weaver et al., Chap. 38, this volume). In the interval of pelagic clays and thin calcareous turbidites below the major disconformity, the sediment accumulation rate from 26.0 to $37.1 \mathrm{Ma}$ (late Eocene to Oligocene) is $3 \mathrm{~m} / \mathrm{m}$.y., only slightly more than the overall pelagic accumulation rate for this interval. This low rate is caused by the thin infrequent calcareous turbidites and thick red clays in this interval.

\section{Site 951}

\section{Pelagic Sediment Accumulation Rates}

The pelagic age-thickness plot for Site 951 is similar to the Neogene section of the plot for Site 950. Between 0 and 2.6 Ma (late Pliocene-Pleistocene), pelagic sediment accumulated at $4.6 \mathrm{~m} / \mathrm{m} . \mathrm{y}$. (Fig. 7), which is essentially the same as the rate at Site 950. From 2.6 to $4.8 \mathrm{Ma}$ (early to early late Pliocene) the rate decreases sharply to 2 $\mathrm{m} / \mathrm{m}$.y., and from 4.8 to $8.2 \mathrm{Ma}$ (late Miocene-earliest Pliocene), the rate decreases further to $1.3 \mathrm{~m} / \mathrm{m}$.y. The overall rate from 2.6 to 8.2 $\mathrm{Ma}$ is $1.6 \mathrm{~m} / \mathrm{m} . \mathrm{y}$., which is very similar to that of Site 950 for the 2.7 to 8.3 -Ma interval. From 8.3 to $17.0 \mathrm{Ma}$ (late early to early late Miocene) at the bottom of the hole, the rate is $0.5 \mathrm{~m} / \mathrm{m}$.y., again very similar to the rate over the same interval in Site 950.

\section{Total Sediment Accumulation Rates}

Total sediment accumulation rates at Site 951 for the Neogene are similar to those from Site 950, except in the early and middle Miocene sections, where the rates are markedly higher. From 0 to $1.1 \mathrm{Ma}$ (late Pleistocene), the total accumulation rate is $30 \mathrm{~m} / \mathrm{m} . \mathrm{y}$. , and from 1.1 to $2.6 \mathrm{Ma}$ (late Pliocene/early Pleistocene), the rate is $28 \mathrm{~m} / \mathrm{m}$.y (Fig. 8). From 2.6 to $2.9 \mathrm{Ma}$ (late Pliocene), the rate is a high $47 \mathrm{~m} /$ m.y. The overall rate from 0 to $2.9 \mathrm{Ma}$ is $35 \mathrm{~m} / \mathrm{m}$.y., a rate similar to that at Site 950 . The rate from 2.9 to $5.8 \mathrm{Ma}$ (latest Miocene-late Pliocene) decreases to $28.5 \mathrm{~m} / \mathrm{m}$.y., below which there is a short interval from 5.8 to $6.5 \mathrm{Ma}$ (late Miocene), which apparently has a high rate of $47 \mathrm{~m} / \mathrm{m}$.y. The overall rate from 2.9 to $6.5 \mathrm{Ma}$ is $32 \mathrm{~m} / \mathrm{m}$.y. This higher rate is perhaps because of individual turbidites during this time being thicker at this site than at Site 950 . From 6.5 to $8.3 \mathrm{Ma}$ (late Miocene), the rate decreases to $10 \mathrm{~m} / \mathrm{m}$.y.; from 8.3 to $10.8 \mathrm{Ma}$ (early late Miocene), it decreases to $4 \mathrm{~m} / \mathrm{m}$.y. This gives a slightly lower rate than for the same interval at Site 950. The rate from 10.8 to $13.2 \mathrm{Ma}$ is $7 \mathrm{~m} / \mathrm{m}$.y., below which the rate increases to $15 \mathrm{~m} / \mathrm{m} . \mathrm{y}$. between 13.2 and $16 \mathrm{Ma}$. From 16 to $17 \mathrm{Ma}$, the rate increases dramatically to $30 \mathrm{~m} / \mathrm{m}$.y. These increased rates are significantly higher than for the same interval at Site 950.

\section{Site 952}

\section{Pelagic Sediment Accumulation Rates}

The pelagic age-thickness plot for Site 952 is broadly similar to that for Site 951 and the Neogene section of Site 950. The similarity of the pelagic accumulation rates between the three sites reflects a 
Table 7. Nannofossil and paleomagnetic datums used in construction of age-depth and pelagic age-thickness plots, Hole 952A.

\begin{tabular}{|c|c|c|c|c|c|c|c|c|}
\hline & \multirow[b]{2}{*}{ Event } & \multicolumn{2}{|c|}{ Core, section, interval } & \multicolumn{2}{|c|}{ Depth } & \multicolumn{2}{|c|}{ Pelagic thickness } & \multirow{2}{*}{$\begin{array}{l}\text { Age } \\
\text { (Ma) }\end{array}$} \\
\hline & & Top $(\mathrm{cm})$ & Bottom $(\mathrm{cm})$ & Top (mbsf) & Bottom (mbsf) & Top (m) & Bottom (m) & \\
\hline 1 & HO P. lacunosa & 952A-3H-5, 111 & $952 \mathrm{~A}-3 \mathrm{H}-6,72$ & 25.98 & 27.09 & 1.97 & 2.60 & 0.46 \\
\hline 2 & Brunhes bottom & $952 \mathrm{~A}-4 \mathrm{H}-6,70-90$ & - & 36.78 & - & 3.17 & - & 0.78 \\
\hline 3 & HO R.asanoi & $952 \mathrm{~A}-4 \mathrm{H}-2,48$ & $952 \mathrm{~A}-4 \mathrm{H}-3,69$ & 30.56 & 32.27 & 2.87 & 3.03 & 0.83 \\
\hline 4 & Jaramillo top & $952 \mathrm{~A}-6 \mathrm{H}-2,15-50$ & - & 49.22 & - & 4.46 & - & 0.99 \\
\hline 5 & Jaramillo bottom & $952 \mathrm{~A}-6 \mathrm{H}-6,40-60$ & - & 55.47 & - & 5.82 & - & 1.07 \\
\hline 6 & HO Gephyrocapsa spp. $>4 \mu \mathrm{m}$ & $952 \mathrm{~A}-6 \mathrm{H}-3,39$ & $952 \mathrm{~A}-6 \mathrm{H}-6,43$ & 50.96 & 55.50 & 4.73 & 5.85 & 1.24 \\
\hline 7 & Olduvai top & $952 \mathrm{~A}-8 \mathrm{H}-1,20$ & - & 66.86 & - & 8.02 & - & 1.77 \\
\hline 8 & HO D.brouweri & $952 \mathrm{~A}-8 \mathrm{H}-5,18$ & $952 \mathrm{~A}-8 \mathrm{H}-6,68$ & 72.80 & 74.80 & 8.40 & 9.79 & 1.95 \\
\hline 9 & Olduvai bottom & $952 \mathrm{~A}-8 \mathrm{H}-6,30$ & $952 \mathrm{~A}-9 \mathrm{H}-2,80$ & 74.42 & 78.00 & 9.5 & 10.25 & 1.95 \\
\hline 10 & LO D.triradiatus & $952 \mathrm{~A}-9 \mathrm{H}-2,116$ & $952 \mathrm{~A}-9 \mathrm{H}-5,14.5$ & 78.36 & 81.85 & 10.35 & 10.52 & 2.15 \\
\hline 11 & HO D.pentaradiatus & 952A-9H-6, 127.5 & $952 \mathrm{~A}-10 \mathrm{H}-1,108.5$ & 84.47 & 86.89 & 10.78 & 11.11 & 2.44 \\
\hline 12 & Gauss top & $952 \mathrm{~A}-10 \mathrm{H}-1,60$ & $952 \mathrm{~A}-10 \mathrm{H}-6,120$ & 86.40 & 94.51 & 11.02 & 11.18 & 2.60 \\
\hline 13 & HO D. surculus & $952 \mathrm{~A}-10 \mathrm{H}-1,108.5$ & $952 \mathrm{~A}-10 \mathrm{H}-6,119$ & 86.89 & 94.50 & 11.11 & 11.17 & 2.61 \\
\hline 14 & HO D. tamalis & 952A-10H-6, 119 & $952 \mathrm{~A}-11 \mathrm{H}-2,70$ & 94.50 & 97.50 & 11.17 & 11.44 & 2.76 \\
\hline 15 & HO R.pseudoumbilicus & $952 \mathrm{~A}-13 \mathrm{H}-6,89$ & $952 \mathrm{~A}-14 \mathrm{H}-2,17$ & 122.63 & 125.47 & 12.10 & 12.20 & 3.77 \\
\hline 16 & LO D. tamalis & $952 \mathrm{~A}-15 \mathrm{H}-3,61$ & $952 \mathrm{~A}-15 \mathrm{H}-5,120$ & 136.79 & 140.28 & 12.56 & 12.83 & 4.01 \\
\hline 17 & HO Amaurolithus spp. & $952 \mathrm{~A}-15 \mathrm{H}-5,120$ & $952 \mathrm{~A}-16 \mathrm{X}-2,83$ & 140.28 & 144.51 & 12.83 & 12.94 & 4.39 \\
\hline 18 & LO D. asymmetricus & $952 \mathrm{~A}-18 \mathrm{X}-4,91$ & $952 \mathrm{~A}-19 \mathrm{X}-1,115$ & 160.86 & 166.28 & 13.64 & 13.99 & 4.79 \\
\hline 19 & LO C.rugosus & 952A-19X-1, 115 & 952A-19X-6, 58 & 166.28 & 173.12 & 13.99 & 14.32 & 5.04 \\
\hline 20 & HO D. quinqueramus & $952 \mathrm{~A}-20 \mathrm{X}-4,31$ & $952 \mathrm{~A}-20 \mathrm{X}-4,139$ & 179.62 & 180.68 & 14.63 & 14.77 & 5.4 \\
\hline 21 & HO A. amplificus & $952 \mathrm{~A}-21 \mathrm{X}-1,13$ & $952 \mathrm{~A}-21 \mathrm{X}-1,93$ & 184.63 & 185.40 & 14.90 & 15.09 & 5.8 \\
\hline 22 & HO $R$. rotaria & $952 \mathrm{~A}-21 \mathrm{X}-1,13$ & $952 \mathrm{~A}-21 \mathrm{X}-1,93$ & 184.63 & 185.40 & 14.90 & 15.09 & 6.1 \\
\hline 23 & LO A. amplificus & $952 \mathrm{~A}-23 \mathrm{X}-5,10$ & $952 \mathrm{~A}-23 \mathrm{X}-7,33$ & 209.75 & 212.89 & 15.88 & 16.01 & 6.5 \\
\hline 24 & LO $R$. pseudoumbilicus $>7 \mu \mathrm{m}$ & 952A-24X-2, 14.5 & $952 \mathrm{~A}-24 \mathrm{X}-2,59$ & 215.02 & 215.46 & 16.15 & 16.22 & 6.6 \\
\hline 25 & LO A. delicatus & $952 \mathrm{~A}-24 \mathrm{X}-2,59$ & $952 \mathrm{~A}-24 \mathrm{X}-5,69$ & 215.46 & 219.98 & 16.22 & 16.92 & 6.8 \\
\hline 26 & LO $R$. rotaria & $952 \mathrm{~A}-24 \mathrm{X}-5,69$ & $952 \mathrm{~A}-25 \mathrm{X}-6,10$ & 219.98 & 230.58 & 16.92 & 17.38 & 6.9 \\
\hline 27 & LO A. primus & 952A-25X-CC, 26 & $952 \mathrm{~A}-26 \mathrm{X}-1,58$ & 231.01 & 233.18 & 17.41 & 17.41 & 7.2 \\
\hline 28 & LO D. quinqueramus & $952 \mathrm{~A}-26 \mathrm{X}-3,96$ & $952 \mathrm{~A}-27 \mathrm{X}-1,144.5$ & 236.53 & 243.68 & 17.58 & 18.12 & 8.2 \\
\hline 29 & $\mathrm{HO}$ R. pseudoumbilicus $>7 \mu \mathrm{m}$ & $952 \mathrm{~A}-27 \mathrm{X}-4,128$ & $952 \mathrm{~A}-27 \mathrm{X}-\mathrm{CC}, 5$ & 248.01 & 249.77 & 18.44 & 18.82 & 8.6 \\
\hline 30 & LO M. convallis & $952 \mathrm{~A}-28 \mathrm{X}-1,113.5$ & $952 \mathrm{~A}-28 \mathrm{X}-3,11.5$ & 252.97 & 254.92 & 18.97 & 19.28 & 9.7 \\
\hline 31 & LO D. hamatus & $952 \mathrm{~A}-28 \mathrm{X}-3,97$ & $952 \mathrm{~A}-29 \mathrm{X}-1,110.5$ & 255.78 & 262.69 & 19.40 & 19.59 & 10.4 \\
\hline 32 & LO C. coalitus & 952A-29X-3, 53 & $952 \mathrm{~A}-29 \mathrm{X}-4,8$ & 265.07 & 266.11 & 19.80 & 19.96 & 10.6 \\
\hline 33 & LO D. kugleri & $952 \mathrm{~A}-30 \mathrm{X}-2,145$ & $952 \mathrm{~A}-30 \mathrm{X}-4,122$ & 274.19 & 276.91 & 20.90 & 21.14 & 12.0 \\
\hline 34 & LO T. rugosus & $952 \mathrm{~A}-31 \mathrm{X}-3,26$ & $952 \mathrm{~A}-31 \mathrm{X}-6,28$ & 284.17 & 288.65 & 21.63 & 22.21 & 13.0 \\
\hline 35 & LO R. pseudoumbilicus $>7 \mu \mathrm{m}$ & $952 \mathrm{~A}-32 \mathrm{X}-2,21$ & $952 \mathrm{~A}-32 \mathrm{X}-4,34$ & 292.26 & 295.30 & 22.58 & 22.85 & 13.1 \\
\hline 36 & LO D. signus & $952 \mathrm{~A}-40 \mathrm{X}-5,32$ & $952 \mathrm{~A}-40 \mathrm{X}-6,99$ & 374.24 & 376.41 & 26.72 & 26.72 & 16.0 \\
\hline 37 & LO D. exilis & $952 \mathrm{~A}-45 \mathrm{X}-6,25$ & - & 423.90 & - & 27.88 & - & $<=17.0$ \\
\hline
\end{tabular}

Note: Pliocene-Quaternary datums are from Schmincke, Weaver, Firth, et al. (1995), with the ages assigned to them taken from Curry, Shackleton, Richter, et al. (1995).

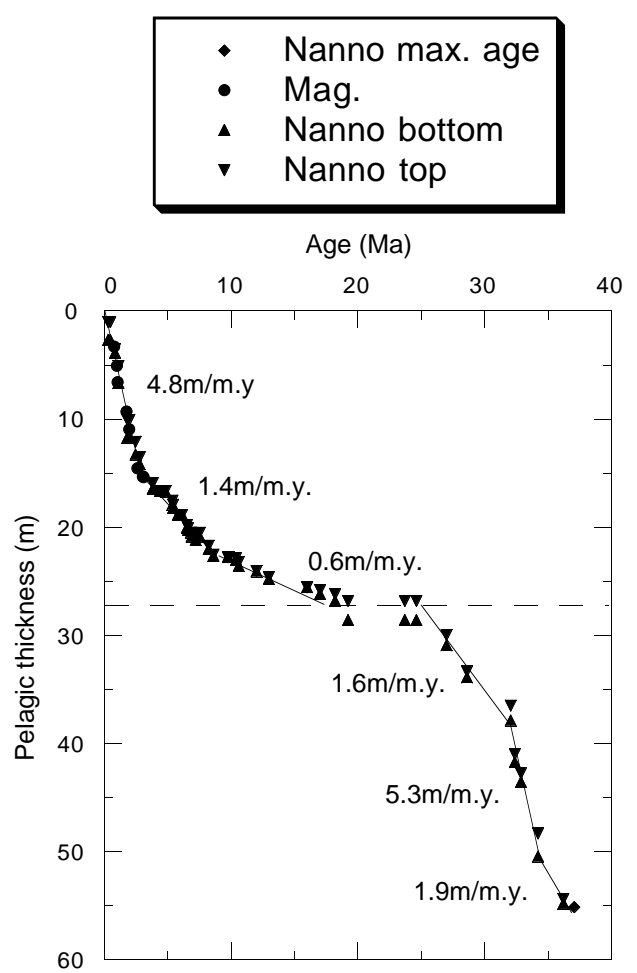

Figure 5. Pelagic age-thickness plot for Hole 950A. Pairs of opposed solid triangles $=$ the thickness range of each nannofossil datum. Solid diamond $=$ nannofossil event at the bottom of the hole, which gives a maximum age. Solid circles = paleomagnetic datums .

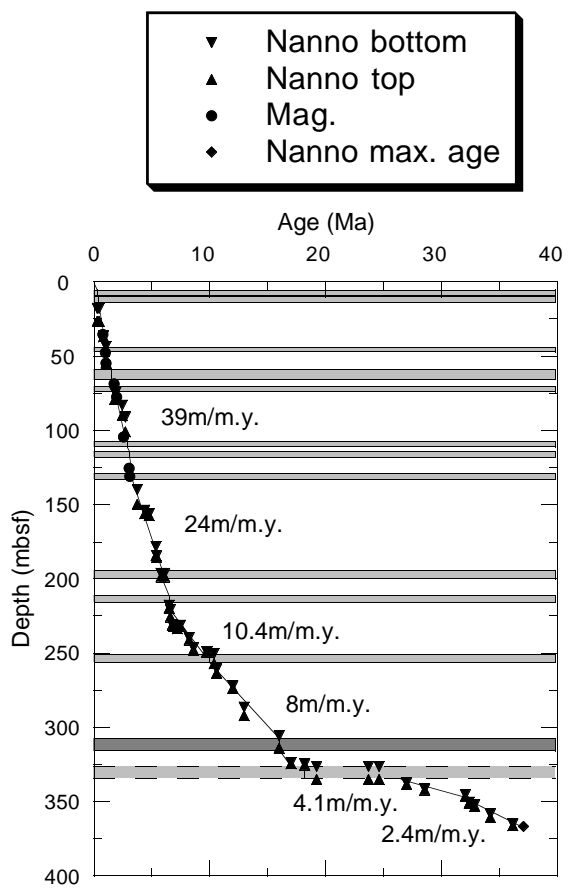

Figure 6. Age-depth plot for Hole 950A. Light gray bars = individual turbidites thicker than $3 \mathrm{~m}$. Darker gray bar = Cruiser turbidite. Pairs of opposed solid triangles $=$ depth range of each nannofossil datum. Solid diamond $=$ nannofossil event at the bottom of the hole, which gives a maximum age. Solid circles $=$ paleomagnetic datums . 


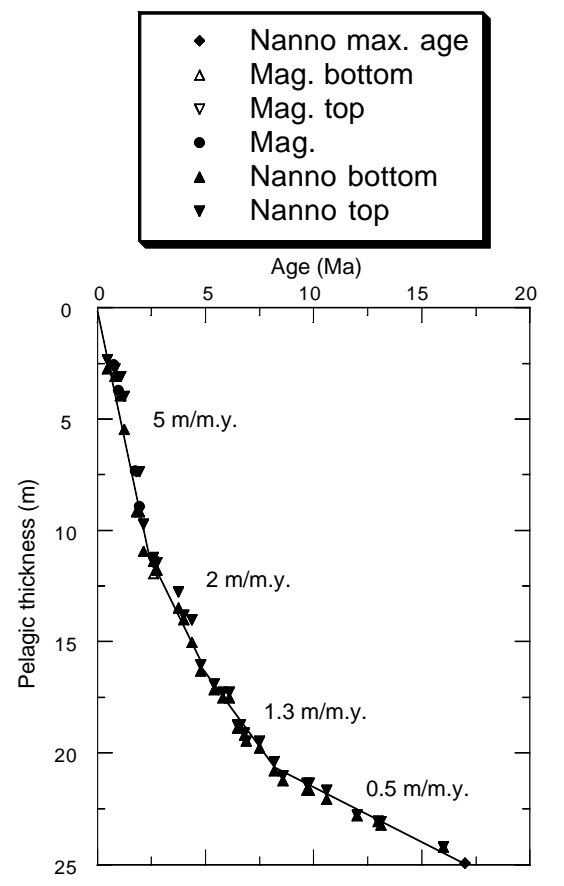

Figure 7. Composite pelagic age-thickness plot for Holes 951A and 951B. Pairs of opposed solid triangles $=$ thickness range of each nannofossil datum. Solid diamond $=$ nannofossil event at the bottom of the hole, which gives a maximum age. Solid circles = paleomagnetic datums, and opposed pairs of open triangles $=$ paleomagnetic datum over a depth range.

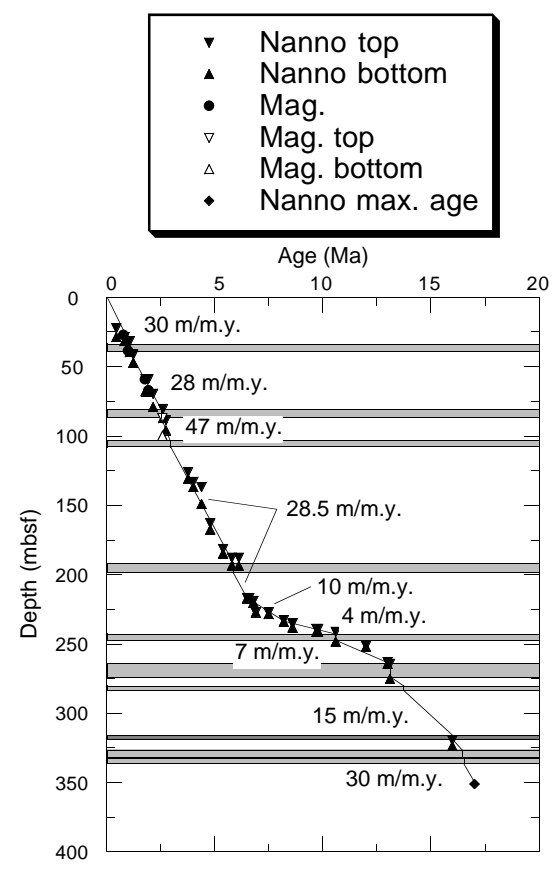

Figure 8. Composite age-depth plot for Holes 951A and 951B. Light gray bars $=$ individual turbidites thicker than $3 \mathrm{~m}$. Dark gray bar $=$ Cruiser turbidite. Pairs of opposed solid triangles $=$ the depth range of each nannofossil datum. Solid diamond $=$ nannofossil event at the bottom of the hole, which gives a maximum age. Solid circles = paleomagnetic datums, and opposed pairs of open triangles $=$ paleomagnetic datum over a depth range.

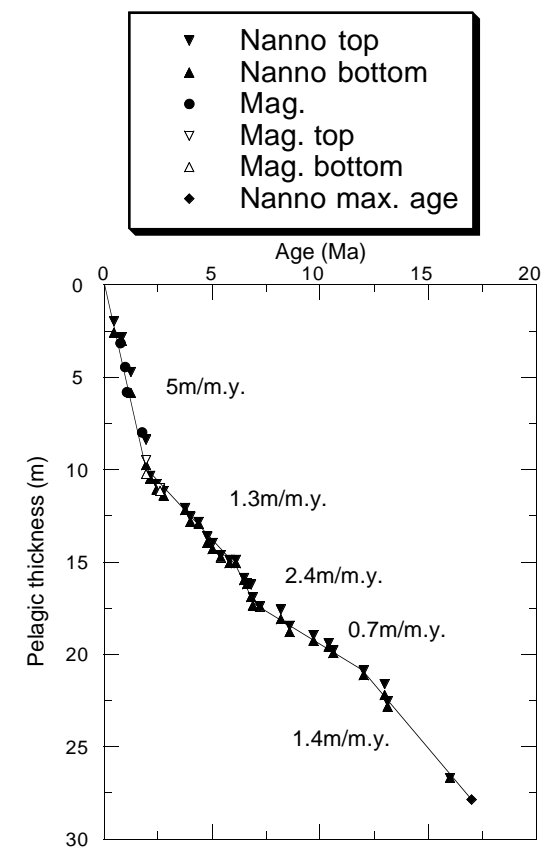

Figure 9. Pelagic age-thickness plot for Hole 952A. Pairs of opposed solid triangles $=$ thickness range of each nannofossil datum. Solid diamond $=$ nannofossil event at the bottom of the hole, which gives a maximum age. Solid circles $=$ paleomagnetic datums, and opposed pairs of open triangles $=$ paleomagnetic datum over a depth range.

background regime of pelagic sedimentation that is similar over large areas of the MAP, as would be expected on an abyssal plain where incoming turbidites are generally not erosive (Weaver, 1994). Between 0 and 2.4 Ma (latest Pliocene-Quaternary), the pelagic accumulation rate is $5 \mathrm{~m} / \mathrm{m}$.y. (Fig. 9), decreasing to $1.3 \mathrm{~m} / \mathrm{m}$.y. between 2.4 and 6.0 Ma (latest Miocene-late Pliocene). The rate increases to $2.4 \mathrm{~m} / \mathrm{m}$.y between 6.0 and 6.9 Ma (late Miocene) and then decreases again to $0.7 \mathrm{~m} / \mathrm{m}$.y. between 6.9 and $11.9 \mathrm{Ma}$. The rate between 11.9 Ma and the base of the hole at $17.0 \mathrm{Ma}$ is $1.4 \mathrm{~m} / \mathrm{m}$.y., which is more than double the rate for the same interval in the other two sites. The depth to seismic reflector maps of Rothwell et al. (Chap. 28, this volume) show that seismic reflector R4 (which correlates to the Cruiser turbidite at $\sim 15.8 \mathrm{Ma}$ ) is $\sim 50 \mathrm{~m}$ deeper at Site 952 than at the other two sites, suggesting that the eastern section of the Cruiser Fracture Zone Valley around Site 952 acted as a local depocenter for both turbidites and pelagic sediment.

\section{Total Sediment Accumulation Rates}

Total sediment accumulation rates at Site 952 are similar to those from the Neogene section of Site 950 and those from Site 951, except in the early and middle Miocene, where the rates are much higher. From 0 to $6.4 \mathrm{Ma}$ (latest Miocene-Quaternary), the rate is $33 \mathrm{~m} / \mathrm{m}$.y. (Fig. 10), slightly higher than the overall rates for the same interval at the other two sites. From 6.4 to $7.2 \mathrm{Ma}$ (late Miocene), the rate rises to $37 \mathrm{~m} / \mathrm{m}$.y., falling to $11 \mathrm{~m} / \mathrm{m}$.y. between 7.2 and $8.1 \mathrm{Ma}$ (late Miocene), and falling further to $6.2 \mathrm{~m} / \mathrm{m}$.y. between 8.1 and $10.3 \mathrm{Ma}$ (early late Miocene). From 10.3 to $13.0 \mathrm{Ma}$ (late middle Miocene to early late Miocene), the rate is $9 \mathrm{~m} / \mathrm{m}$.y. Overall, the rates from 7.2 to 13.0 $\mathrm{Ma}$ are similar to those of Site 951. From 13.0 Ma to the Cruiser turbidite at $15.8 \mathrm{Ma}$, the rate increases dramatically to $32 \mathrm{~m} / \mathrm{m} . \mathrm{y}$., below which it increases further to $95 \mathrm{~m} / \mathrm{m}$.y. between 15.8 and $16.1 \mathrm{Ma}$. The oldest section of the hole, from 16.1 to $\sim 17.0 \mathrm{Ma}$, has a lower but still high rate of $40 \mathrm{~m} / \mathrm{m}$.y. As noted above, these high rates suggest 


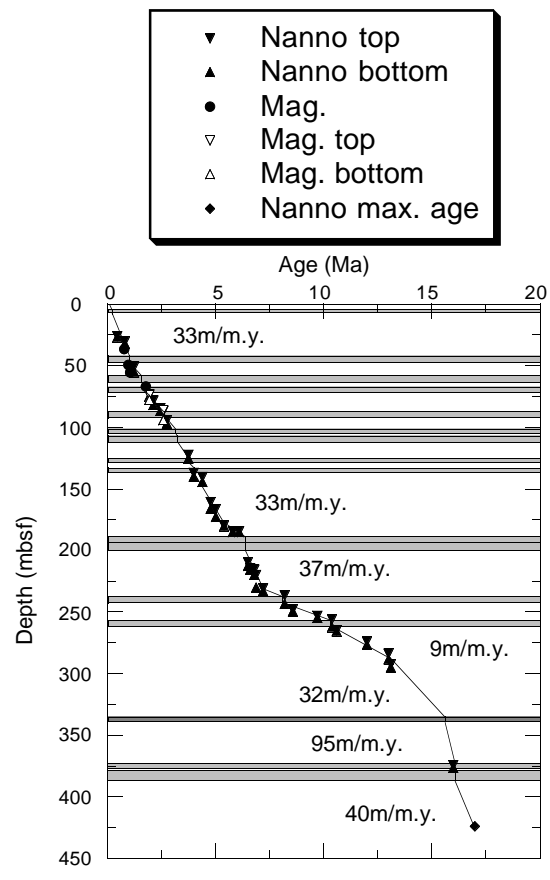

Figure 10. Age-depth plot for Hole 952A. Light gray bars = individual turbidites thicker than $3 \mathrm{~m}$. Dark gray bar $=$ Cruiser turbidite. Pairs of opposed solid triangles $=$ depth range of each nannofossil datum. Solid diamond $=$ nannofossil event at the bottom of the hole, which gives a maximum age. Solid circles $=$ paleomagnetic datums, and opposed pairs of open triangles $=$ paleomagnetic datum over a depth range.

that the area around Site 952 acted as a local depocenter, particularly during the early and middle Miocene.

\section{CONCLUSIONS}

The revised biostratigraphy presented here has permitted detailed lithologic correlation between the Neogene sections of all three MAP sites (see Lebreiro et al., Chap. 30, this volume) and has accurately established the age of the Paleogene section of Site 950. This represents a significant improvement over the shipboard biostratigraphy for the late Eocene-Miocene sequences of the three sites (see Schmincke, Weaver, Firth, et al., 1995) and has been achieved by using nannofossil LO's from turbidites combined with secondary LO events to mark zonal boundaries based on HO's found to be reworked. The shipboard biostratigraphy was based on pelagic sediments wherever possible, so resolution was very low in the late Eocene-Miocene section, where pelagic sediments are generally barren.

The biostratigraphy and sediment accumulation rates of the Miocene sections at all three sites are broadly similar. All Miocene zones from Zone CN9 to the upper part of Zone CN3 are present at each site, except Site 951, where Zone CN7 is missing in an interval of disturbed and missing core. The upper part of Zone CN3 is the oldest zone present at Sites 951 and 952 . Total sediment accumulation rates for the Miocene of the three sites are high because of the frequent influx of turbidites, with the highest rate calculated being $95 \mathrm{~m} / \mathrm{m}$.y. between 15.8 and 16.1 Ma at Site 952 . Rates of $\sim 5-40 \mathrm{~m} / \mathrm{m} . \mathrm{y}$. are more typical. The higher rates at Site 952 are thought to reflect its position in a part of the Cruiser Fracture Zone Valley, which had a significantly deeper early and middle Miocene paleodepth than the other two sites (Rothwell et al., Chap. 28, this volume). Pelagic accumulation rates are more similar among the three sites than the total accumulation rates, reflecting an essentially constant pelagic sediment flux over large areas of the MAP. A minor hiatus (17.1-18.2 Ma) occurs at Site 950, between the upper part of Zone CN3 and a single sandy calcareous turbidite belonging to Zone $\mathrm{CN} 2$.

A major disconformity separates this turbidite from the underlying red clays and thin calcareous turbidites of late Eocene-Oligocene age, with a time break of $\sim 8.3 \mathrm{Ma}$, from 18.2 to $26.5 \mathrm{Ma}$. This Paleogene sequence contains all zones from Subzone CP19b to Subzone CP15a. Subzones CP16a and 16b could not be separated because of reworking. Total sediment accumulation rates for this interval are lower than in the Miocene, reflecting the input of thin, infrequent calcareous turbidites, rather than the frequent, voluminous turbidites of the Miocene. Pelagic sediment accumulation rates in the Paleogene section at Site 950 are higher than for the red clays of the early Miocene section above as a result of the input of fine-grained volcaniclastic material from the volcanoes of the Great Meteor Seamount Chain. These results strongly suggest that viable and accurate biostratigraphies are attainable from abyssal plain sequences, which are dominated by turbidites interbedded with barren pelagic red clays.

\section{ACKNOWLEDGMENTS}

I am very grateful to ODP and the Australian ODP Secretariat for inviting me to participate during Leg 157. Drs. D.K. Watkins, D.W. Haig, and J.P. Rexilius are thanked for introducing me to the fascinating world of nannofossils and for their encouragement ever since. Special thanks are due to my shipboard colleagues and the ODP staff, who made the cruise a pleasure, and my colleagues and friends at the University of Western Australia, the former Institute of Oceanographic Sciences Deacon Laboratory, and the Southampton Oceanography Centre, especially Sharon Nixon, Silke Severmann, and Drs. Phil Weaver, Susana Lebreiro, and Pascal Luxey. Dr. Stefan Gartner and an anonymous reviewer are thanked for their constructive reviews of this paper.

During Leg 157, I was receiving a University Research Scholarship from the University of Western Australia for which I am grateful. This work was supported by the European Commission on Marine Science and Technology (MAST II) program (Sediment Transport on European Atlantic Margins [STEAM] Project; grant MAS2CT94-0083).

\section{REFERENCES}

Aubry, M.-P., 1990. Handbook of Cenozoic Calcareous Nannoplankton (Book 4): Heliolithae (Helicoliths, Cribriliths, Lopadoliths, and Others): New York (Micropaleontology Press).

Bukry, D., 1973. Low-latitude coccolith biostratigraphic zonation. In Edgar, N.T., Saunders, J.B., et al., Init. Repts. DSDP, 15: Washington (U.S. Govt. Printing Office), 685-703.

1975. Coccolith and silicoflagellate stratigraphy, northwestern Pacific Ocean, Deep Sea Drilling Project Leg 32. In Larson, R.L., Moberly, R., et al., Init. Repts. DSDP, 32: Washington (U.S. Govt. Printing Office), 677-701.

Cande, S.C., and Kent, D.V., 1992. A new geomagnetic polarity time scale for the Late Cretaceous and Cenozoic. J. Geophys. Res., 97:1391713951.

Crowley, T.J., 1983. Calcium carbonate preservation patterns in the central North Atlantic during the last 150,000 years. Mar. Geol., 51:1-41.

Curry, W.B., Shackleton, N.J., Richter, C., et al., 1995. Proc. ODP, Init. Repts., 154: College Station, TX (Ocean Drilling Program).

De Lange, G.J., Jarvis, I., and Kuijpers, A., 1987. Geochemical characteristics and provenance of late Quaternary sediments from the Madeira Abyssal Plain, North Atlantic. In Weaver, P.P.E., and Thomson, J. (Eds.), Geology and Geochemistry of Abyssal Plains. Geol. Soc. Spec. Publ. London, 31:147-165.

Gartner, S., 1992. Miocene nannofossil chronology in the North Atlantic, DSDP Site 608. Mar. Micropaleontol., 18:307-331. 
Jarvis, I., and Higgs, N., 1987. Trace-element mobility during early diagenesis in distal turbidites: late Quaternary of the Madeira Abyssal Plain, N Atlantic. In Weaver, P.P.E., and Thomson J. (Eds.), Geology and Geochemistry of Abyssal Plains. Geol. Soc. Spec. Publ. London, 31:179214

Okada, H., and Bukry, D., 1980. Supplementary modification and introduction of code numbers to the low-latitude coccolith biostratigraphic zonation (Bukry, 1973; 1975). Mar. Micropaleontol., 5:321-325.

Olafsson, G., 1989. Quantitative calcareous nannofossil biostratigraphy of upper Oligocene to middle Miocene sediment from ODP Hole 667A and middle Miocene sediment from DSDP Site 574. In Ruddiman, W., Sarnthein, M., et al., Proc. ODP, Sci. Results, 108: College Station, TX (Ocean Drilling Program), 9-22.

Perch-Nielsen, K., 1985. Cenozoic calcareous nannofossils. In Bolli, H.M., Saunders, J.B., and Perch-Nielsen, K. (Eds.), Plankton Stratigraphy: Cambridge (Cambridge Univ. Press), 427-554.

Raymo, M.E., 1994. The initiation of Northern Hemisphere glaciation. Аnпи. Rev. Earth Planet. Sci., 22:353-383.

Rothwell, R.G., Pearce, T.J., and Weaver, P.P.E., 1992. Late Quaternary evolution of the Madeira Abyssal Plain, Canary Basin, NE Atlantic. Basin Res., 4:103-131.

Schmincke, H.-U., Weaver, P.P.E., Firth, J.V., et al., 1995. Proc. ODP, Init. Repts., 157: College Station, TX (Ocean Drilling Program).]

Searle, R.C., 1987. Regional setting and geophysical characterization of the Great Meteor East area in the Madeira Abyssal Plain. In Weaver, P.P.E., and Thomson, J. (Eds.), Geology and Geochemistry of Abyssal Plains. Geol. Soc. Spec. London, 31:49-70.

Shipboard Scientific Party, 1995a. Site 950. In Schmincke, H.-U., Weaver, P.P.E., Firth, J.V., et al., Proc. ODP, Init. Repts., 157: College Station, TX (Ocean Drilling Program), 51-104.

, 1995b. Site 951. In Schmincke, H.-U., Weaver, P.P.E., Firth, J.V., et al., 1995. Proc. ODP, Init. Repts., 157: College Station, TX (Ocean Drilling Program), 105-134.

1995c. Site 952. In Schmincke, H.-U., Weaver, P.P.E., Firth, J.V., et al., Proc. ODP, Init. Repts., 157: College Station, TX (Ocean Drilling Program), 135-178.

1995d. Site 953. In Schmincke, H.-U., Weaver, P.P.E., Firth, J.V., et al., Proc. ODP, Init. Repts., 157: College Station, TX (Ocean Drilling Program), 317-394.

Theodoridis, S., 1984. Calcareous nannofossil biozonation of the Miocene and revision of the helicoliths and discoasters. Utrecht Micropaleontol. Bull., 32:1-271.

Tucholke, B.E., and Smoot, N.C., 1990. Evidence for age and evolution of corner seamounts and Great Meteor Seamount chain from multibeam bathymetry. J. Geophys. Res., 95:17555-17569.

Varol, O., 1989. Calcareous nannofossil study of the central and western Solomon Islands. In Vedder, J.G., and Bruns, T.R. (Eds.), Geology and Offshore Resources of Pacific Island Arcs: Solomon Islands and Bougainville, Papua New Guinea Regions. Circum-Pacific Council for Energy and Mineral Resources, Earth Sci. Ser., 12:239-268.

Weaver, P.P.E., 1994. Determination of turbidity current erosional characteristics from reworked coccolith assemblages, Canary Basin, North-east Atlantic. Sedimentology, 41:1025-1038.

- 1993. High resolution stratigraphy of marine Quaternary sequences. In Hailwood, E.A., and Kidd, R.B. (Eds.), High Resolution Stratigraphy. Geol. Soc. Spec. Publ. London, 70:137-153.

Weaver, P.P.E., and Kuijpers, A., 1983. Climatic control of turbidite deposition on the Madeira Abyssal Plain. Nature, 306:360-363.

Weaver, P.P.E., Masson, D.G., Gunn, D.E., Kidd, R.B., Rothwell, R.G., and Maddison, D.A., 1995. Sediment mass-wasting in the Canary Basin. In Pickering, K.T., Hiscott, R.N., Kenyon, N.H., Ricci Luchi, F., and Smith, R.D.A. (Eds.), Atlas of Deep Water Environments: Architectural Style in Turbidite Systems: London (Chapman and Hall), 287-296.

Weaver, P.P.E., Rothwell, R.G., Ebbing, J., Gunn, D., and Hunter, P.M., 1992. Correlation, frequency of emplacement and source directions of megaturbidites on the Madeira Abyssal Plain. Mar. Geol., 109:1-20.

Weaver, P.P.E., and Thomson, J., 1993. Calculation erosion by deep-sea turbidity currents during initiation and flow. Nature, 364:136-138.

Weaver, P.P.E., Thomson, J., and Jarvis, I. 1989. The geology and geochemistry of Madeira Abyssal Plain sediments: a review. In Freeman, T.J. (Ed.), Advances in Underwater Technology, Ocean Science and Offshore Engineering (Vol. 18): London (Graham and Trotman), 51-78.

Wei, W., 1996. Calibrations of upper Miocene-Pliocene nannofossil datums with magnetostratigraphy, ODP Site 758 in the equatorial Indian Ocean.
In Flores, J.-A., and Sierro, F.J. (Eds.), Proc. 5th INA Conf., Salamanca. Univ. de Salamanca, INA.

Wei, W., and Peleo-Alampay, A., 1993. Updated Cenozoic nannofossil magnetobiochronology. INA. Newsl., 15:15-21.

Wei, W., and Wise, S.W., Jr., 1990. Middle Eocene to Pleistocene calcareous nannofossils recovered by Ocean Drilling Program Leg 113 in the Weddell Sea. In Barker, P.F., Kennett, J.P., et al., Proc. ODP, Sci. Results, 113: College Station, TX (Ocean Drilling Program), 639-666.

Young, J.R., Flores, J.-A., and Wei, W., 1994. A summary chart of Neogene nannofossil magnetobiostratigraphy. J. Nannoplankton Res., 16:21-27.

\section{Date of initial receipt: 8 July 1996 \\ Date of acceptance: 8 March 1997 \\ Ms 157SR-147}

\section{APPENDIX}

\section{Nannofossil Species Encountered in this Study}

References not cited here can be found in Perch-Nielsen (1985).

Amaurolithus amplificus (Bukry \& Percival, 1971) Gartner \& Bukry (1975)

Amaurolithus delicatus Gartner \& Bukry (1975)

Amaurolithus primus (Bukry \& Percival, 1971) Gartner \& Bukry (1975)

Amaurolithus tricorniculatus (Gartner, 1967) Gartner \& Bukry (1975)

Bicolumnus ovatus Wei \& Wise (1990)

Braarudosphaera bigelowii (Gran \& Braarud, 1935) Deflandre (1947)

Braarudosphaera discula Bramlette \& Riedel (1954)

Bramlettius serraculoides Gartner (1969)

Calcidiscus leptoporus (Murray \& Blackman, 1898) Loeblich \& Tappan (1978)

Calcidiscus macintyrei (Bukry \& Bramlette, 1969) Loeblich \& Tappan (1978)

Calcidiscus premacintyrei Theodoridis (1984)

Calcidiscus protoannulus (Gartner, 1971) Loeblich \& Tappan (1978)

Calcidiscus tropicus (Kamptner, 1955) Varol (1989)

Catinaster calyculus Martini \& Bramlette (1963)

Catinaster coalitus Martini \& Bramlette (1963)

Chiasmolithus altus Bukry \& Percival (1971)

Chiasmolithus grandis (Bramlette \& Riedel, 1954) Radomski (1968)

Chiasmolithus oamaruensis (Deflandre, 1954) Hay et al. (1966)

Chiasmolithus titus Gartner (1970)

Clausicoccus fenestratus (Deflandre \& Fert, 1954) Prins (1979)

Coccolithus formosus (Kamptner, 1963) Wise (1973)

Coccolithus miopelagicus Bukry (1971)

Coccolithus pelagicus (Wallich, 1877) Schiller (1930)

Coronocyclus nitescens (Kamptner, 1963) Bramlette \& Wilcoxon (1967)

Cribrocentrum reticulatum (Gartner \& Smith, 1967) Perch-Nielsen (1971)

Cruciplacolithus tenuiforatus Clochiatti \& Jerkovic (1972)

Cryptococcolithus takayamae Gartner (1992)

Cyclicargolithus abisectus (Müller, 1970) Wise (1973)

Cyclicargolithus floridanus (Roth \& Hay in Hay et al., 1967) Bukry (1971)

Cyclicargolithus luminis (Sullivan, 1965) Bukry (1971)

Dictyococcites bisectus (Hay et al., 1966) Bukry \& Percival (1971)

Dictyococcites daviesii (Haq, 1968) Perch-Nielsen (1971)

Discoaster asymmetricus Gartner (1969)

Discoaster barbadiensis Tan (1927)

Discoaster bellus Bukry \& Percival (1971)

Discoaster berggreni Bukry (1971)

Discoaster bollii Martini \& Bramlette (1963)

Discoaster brouweri Tan (1927) emend. Bramlette \& Riedel (1954)

Discoaster calcaris Gartner (1967)

Discoaster deflandrei Bramlette \& Riedel (1954)

Discoaster druggi Bramlette \& Wilcoxon (1967)

Discoaster hamatus Martini \& Bramlette (1963)

Discoaster kugleri Martini \& Bramlette (1963)

Discoaster loeblichii Bukry (1971)

Discoaster musicus Stradner (1959)

Discoaster neohamatus Bukry \& Bramlette (1969)

Discoaster nodifer (Bramlette \& Riedel, 1954) Bukry (1973)

Discoaster pentaradiatus Tan (1927) emend. Bramlette \& Riedel (1954)

Discoaster prepentaradiatus Bukry \& Percival (1971)

Discoaster pseudovariabilis Martini \& Worsley (1971)

Discoaster quinqueramus Gartner (1969)

Discoaster saipanensis Bramlette \& Riedel (1954) 
Discoaster signus Bukry (1971)

Discoaster surculus Martini \& Bramlette (1963)

Discoaster tanii Bramlette \& Riedel (1954) ssp. ornatus Bramlette \& Wilcoxon (1967)

Discoaster variabilis Martini \& Bramlette (1963)

Geminilithella rotula (Kamptner, 1956) Backman (1980)

Hayaster perplexus (Bramlette \& Riedel, 1954) Bukry (1973)

Hayella aperta Theodoridis (1984)

Hayella challengeri (Müller, 1974) Theodoridis (1984)

Helicosphaera ampliaperta Bramlette \& Wilcoxon (1967)

Helicosphaera bramlettei Müller (1970)

Helicosphaera carteri (Wallich, 1877) Kamptner (1954)

Helicosphaera compacta Bramlette \& Wilcoxon (1967)

Helicosphaera euphratis Haq (1966)

Helicosphaera orientalis Black (1971)

Helicosphaera perch-nielsenae Haq (1971)

Helicosphaera recta Haq (1966)

Helicosphaera reticulata Bramlette \& Wilcoxon (1967)

Helicosphaera scissura Miller (1981)

Helicosphaera stalis Theodoridis (1984)

Helicosphaera walbersdorfensis Müller (1974)

Helicosphaera waltrans Theodoridis (1984)

Helicosphaera wilcoxonii Gartner (1971)

Holodiscolithus macroporus (Deflandre in Deflandre \& Fert, 1954) Roth (1970)

Holodiscolithus solidus (Deflandre in Deflandre \& Fert, 1954) Roth (1970)

Ilselithina fusa Roth (1970)

Isthmolithus recurvus Deflandre in Deflandre \& Fert (1954)

Lithostromation perdurum Deflandre (1942)

Micrantholithus aequalis Sullivan (1964)

Micrantholithus flos Deflandre in Deflandre \& Fert (1954)

Micrantholithus truncus Bramlette \& Sullivan (1961)

Minylitha convallis Bukry (1973)

Pedinocyclus larvalis (Bukry \& Bramlette, 1969) Loeblich \& Tappan (1973)

Pemma papillatum Martini (1959)

Peritrachelina joidesa Bukry \& Bramlette (1968)

Pontosphaera discopora Schiller (1925)

Pontosphaera multipora (Kamptner, 1948) Roth (1970)

Pontosphaera ovata (Levin \& Joerger, 1967) Aubry (1990)
Pontosphaera scissura (Perch-Nielsen, 1971) Romein (1979)

Pyrocyclus hermosus Roth \& Hay in Hay et al. (1967)

Pyrocyclus orangensis (Bukry, 1971) Backman (1980)

Reticulofenestra minuta Roth (1970)

Reticulofenestra minutula (Gartner, 1967) Haq \& Bergrren (1978)

Reticulofenestra pseudoumbilicus (Gartner, 1967) Gartner (1969)

Reticulofenestra rotaria Theodoridis (1984)

Reticulofenestra samodurovii (Hay et al., 1966) Roth (1970)

Reticulofenestra umbilicus (Levin, 1965) Martini \& Ritzkowski (1968)

Rhabdosphaera creber Deflandre in Deflandre \& Fert (1954)

Rhabdosphaera procera Martini (1969)

Rhabdosphaera tenuis Bramlette \& Sullivan (1961)

Scapholithus fossilis Deflandre in Deflandre \& Fert (1954)

Scyphosphaera spp. undet.

Solidopons petrae Theodoridis (1984)

Sphenolithus abies Deflandre in Deflandre \& Fert (1954)

Sphenolithus belemnos Bramlette \& Wilcoxon (1967)

Sphenolithus sp. cf S. capricornutus Bukry \& Percival (1971)

Sphenolithus ciperoensis Bramlette \& Wilcoxon (1967)

Sphenolithus dissimilis Bukry \& Percival (1971)

Sphenolithus distentus (Martini, 1965) Bramlette \& Wilcoxon (1967)

Sphenolithus heteromorphus Deflandre (1953)

Sphenolithus intercalaris Martini (1976)

Sphenolithus moriformis (Brönnimann \& Stradner, 1960) Bramlette \& Wilcoxon (1967)

Sphenolithus predistentus Bramlette \& Wilcoxon (1967)

Sphenolithus pseudoradians Bramlette \& Wilcoxon (1967)

Sphenolithus radians Deflandre in Grassé (1952)

Syracosphaera spp.

Triquetrorhabdulus auritus Stradner \& Allram (1982)

Triquetrorhabdulus carinatus Martini (1965)

Triquetrorhabdulus challengeri Perch-Nielsen (1977)

Triquetrorhabdulus extensus Theodoridis (1984)

Triquetrorhabdulus rioensis Olafsson (1989)

Triquetrorhabdulus rugosus Bramlette \& Wilcoxon (1967)

Triquetrorhabdulus striatus Müller (1974)

Umbilicosphaera sibogae (Weber-van Bosse, 1901) Gaader (1970)

Zygrhablithus bijugatus (Deflandre in Deflandre \& Fert, 1954) Deflandre (1959) 

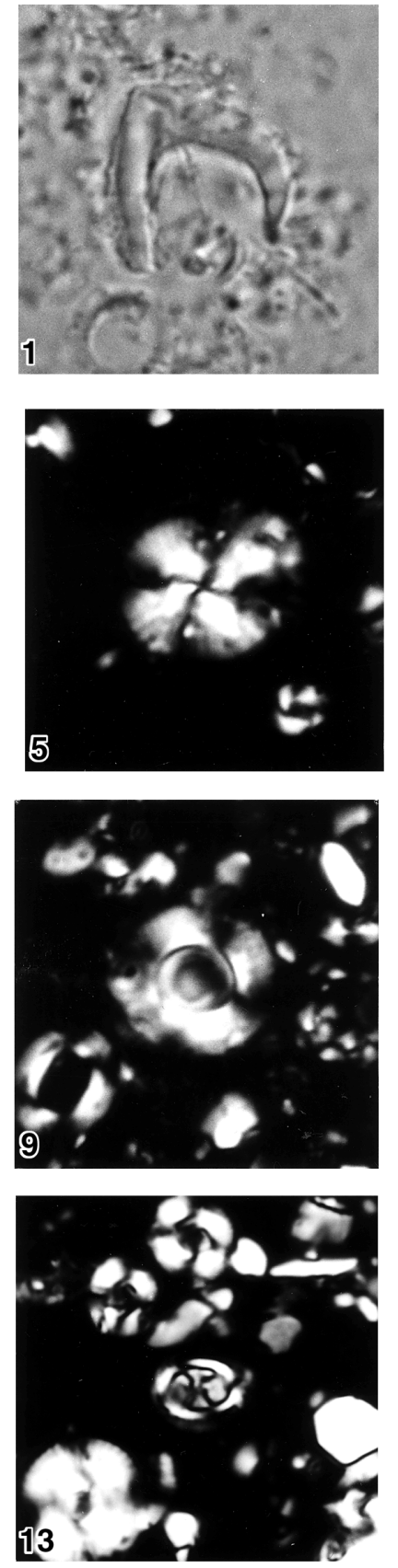
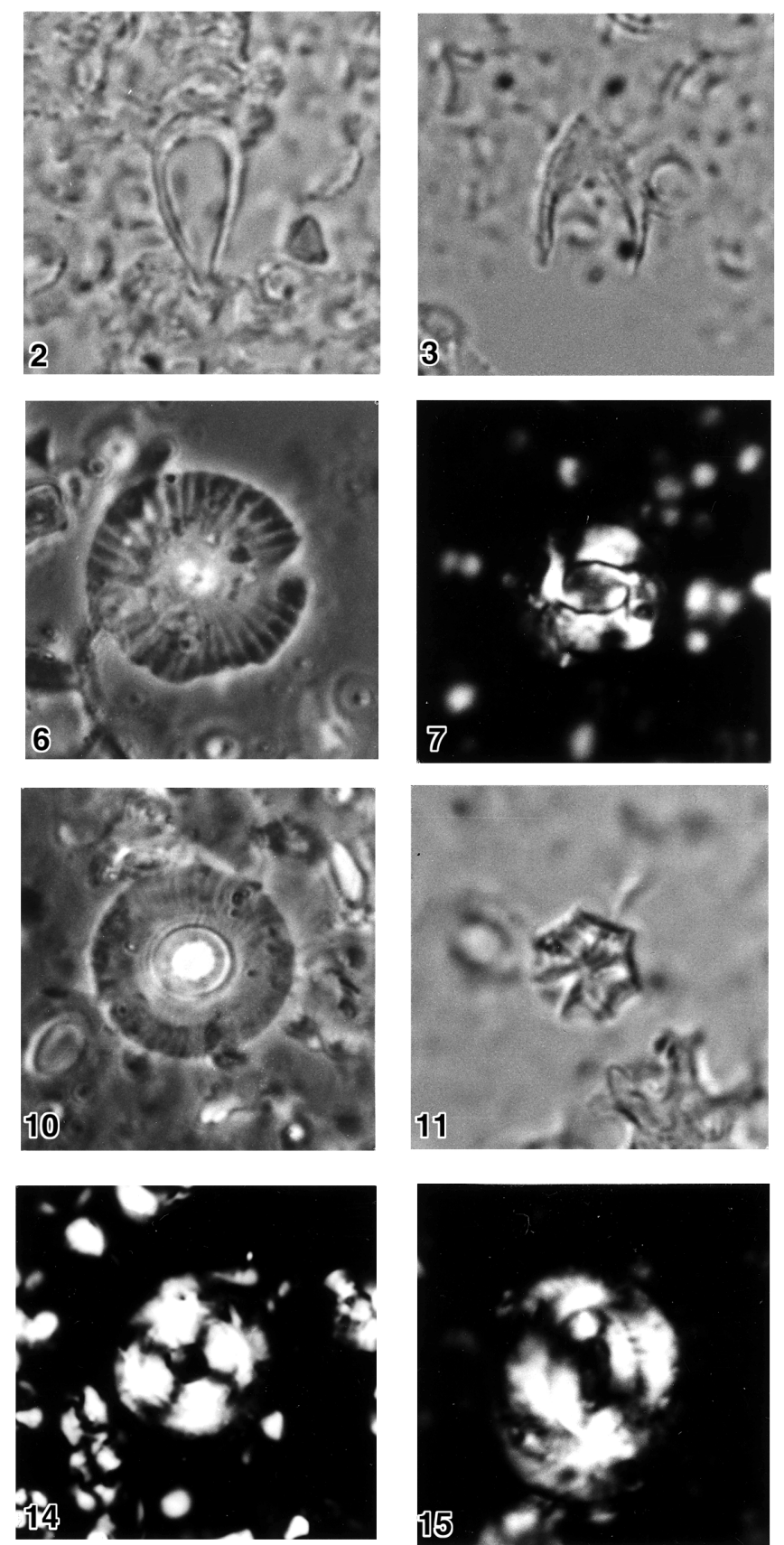
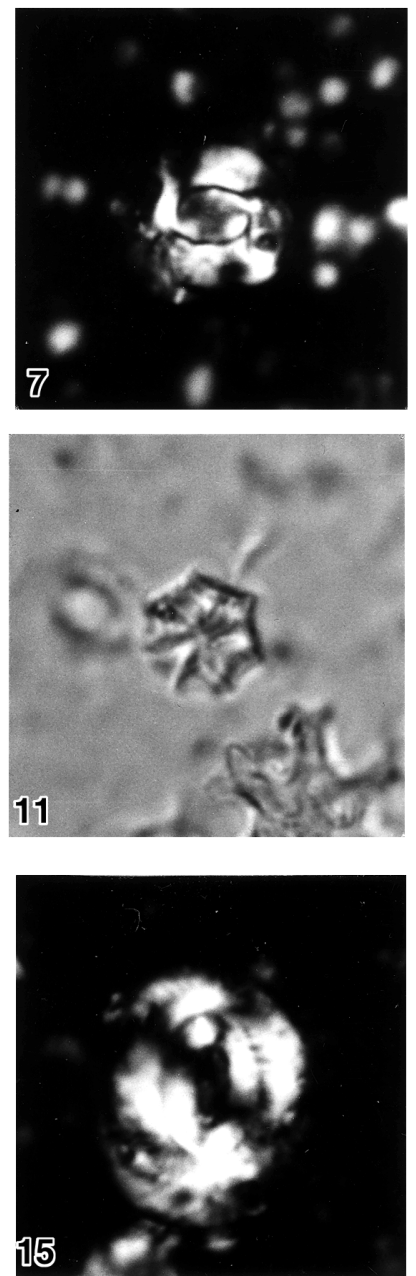
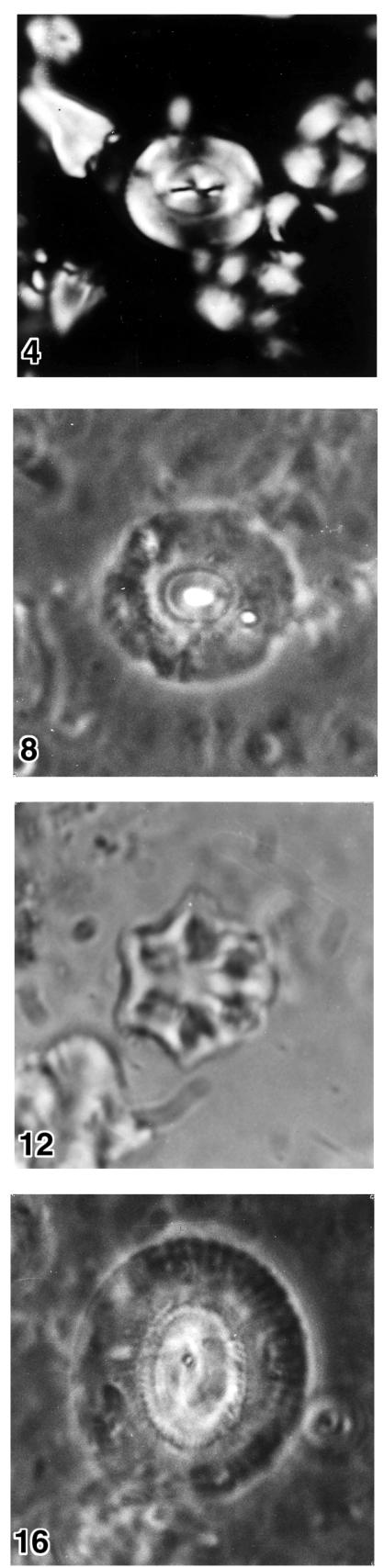

Plate 1. All photographs 1800×. 1. Amaurolithus amplificus, transmitted light (TL), Sample 157-952A-23X-5, $10 \mathrm{~cm}$. 2. Amaurolithus delicatus, TL, Sample 157-952A-23X-5, $10 \mathrm{~cm}$. 3. Amaurolithus primus, TL, Sample 157-952A-25X-CC, $26 \mathrm{~cm}$. 4. Bicolumnus ovatus, cross-polarized light (XPL), Sample 157-950A-38X-4, 88 cm. 5, 6. Calcidiscus macintyrei, 5. XPL, 6. phase-contrast light (PCL), Sample 157-952A-20X-4, $31 \mathrm{~cm}$. 7, 8. Calcidiscus premacintyrei, 7. XPL, 8. PCL, Sample 157-952A-31X-2, 64 cm. 9, 10. Calcidiscus tropicus, 9. XPL, 10. PCL, Sample 157-952A-31X-2, $64 \mathrm{~cm} .11$. Catinaster coalitus, TL, Sample 157-952A-28X-3, $11.5 \mathrm{~cm}$. 12. C. coalitus, TL, Sample 157-952A-29X-2, $29.5 \mathrm{~cm}$. 13. Clausicoccus fenestratus, XPL, Sample 157-950A-38X-4, 88 cm. 14. Coccolithus formosus, XPL, Sample 157-950A-38X-4, 88 cm. 15, 16. C. miopelagicus, 15. XPL, 16. PCL, Sample 157$952 \mathrm{~A}-31 \mathrm{X}-2,64 \mathrm{~cm}$. 

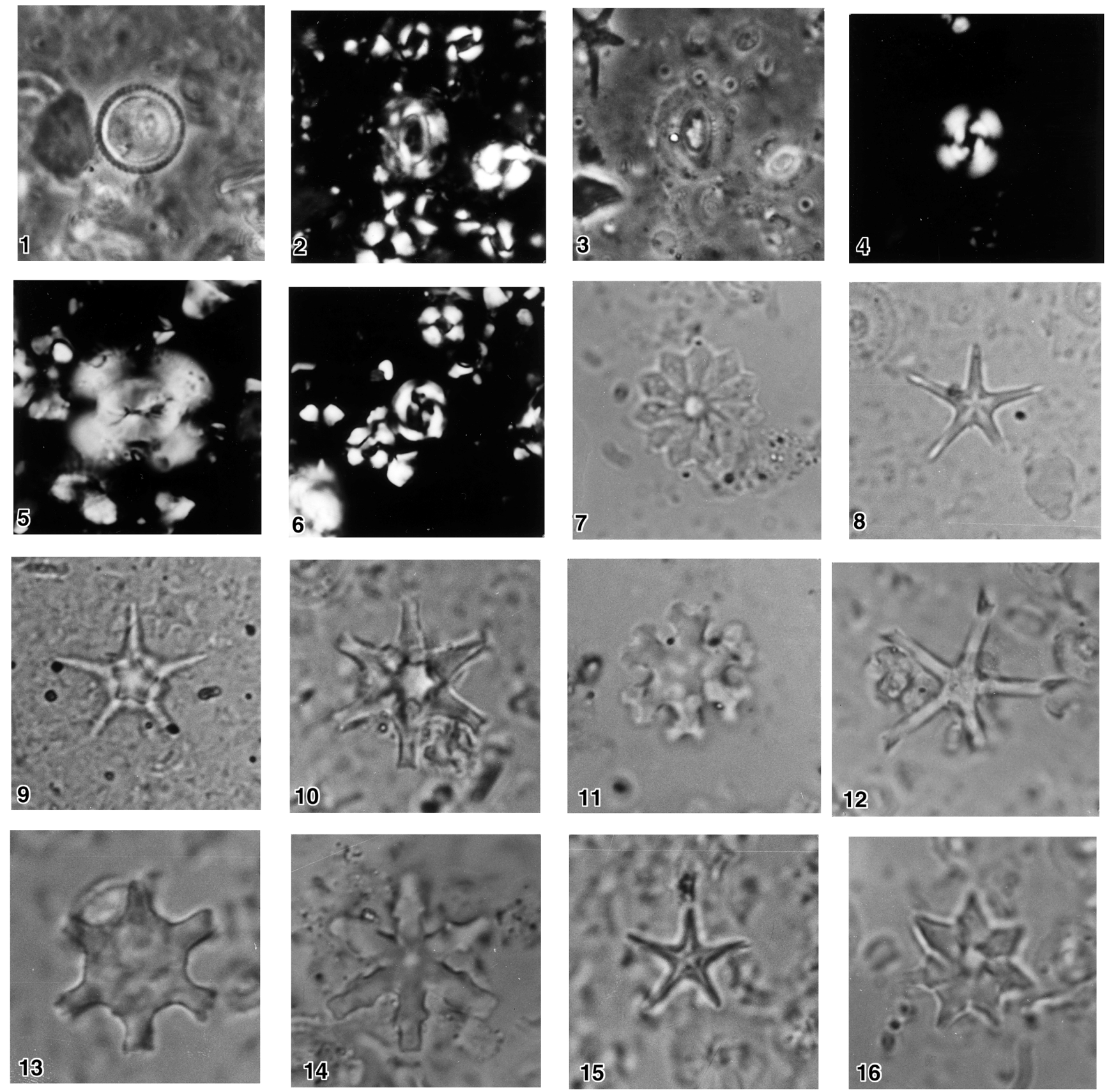

Plate 2. All photographs $1800 \times$, except 12, which is $1420 \times$. 1. Coronocyclus nitescens, PCL, Sample 157-952A-31X-2, $64 \mathrm{~cm}$. 2, 3. Cryptococcolithus takayamae, 2. XPL, 3. PCL, Sample 157-952A-22X-7, $49 \mathrm{~cm}$. 4. Cyclicargolithus floridanus, XPL, Sample 157-952A-45X-6, $25 \mathrm{~cm} .5$. Dictyococcites bisectus, XPL, Sample 157-950A-38X-4, 88 cm. 6. Dictyococcites daviesii, XPL, Sample 157-950A-37X-5, $120 \mathrm{~cm}$. 7. Discoaster barbadiensis, TL, Sample 157-950A-39X-6, 130 cm. 8. Discoaster bellus, TL, Sample 157-952A-28X-3, $11.5 \mathrm{~cm}$. 9. Discoaster berggrenii, TL, Sample 157-952A-23X-4, $41 \mathrm{~cm}$. 10. Discoaster bollii, TL, Sample 157-952A-28X-3, $11.5 \mathrm{~cm}$. 11. Discoaster deflandrei, TL, Sample 157-952A-45X-6, $25 \mathrm{~cm} .12$. Discoaster hamatus, TL, Sample 157-952A-28X-3, 11.5 cm. 13. Discoaster kugleri, TL, Sample 157-952A-29X-6, $110 \mathrm{~cm}$. 14. Discoaster nodifer, TL, Sample 157952A-39X-6, $130 \mathrm{~cm}$. 15. Discoaster quinqueramus, TL, Sample 157-952A-25X-6, $10 \mathrm{~cm}$. 16. Discoaster saipanensis, TL, Sample 157-950A-39X-6, 130 $\mathrm{cm}$. 

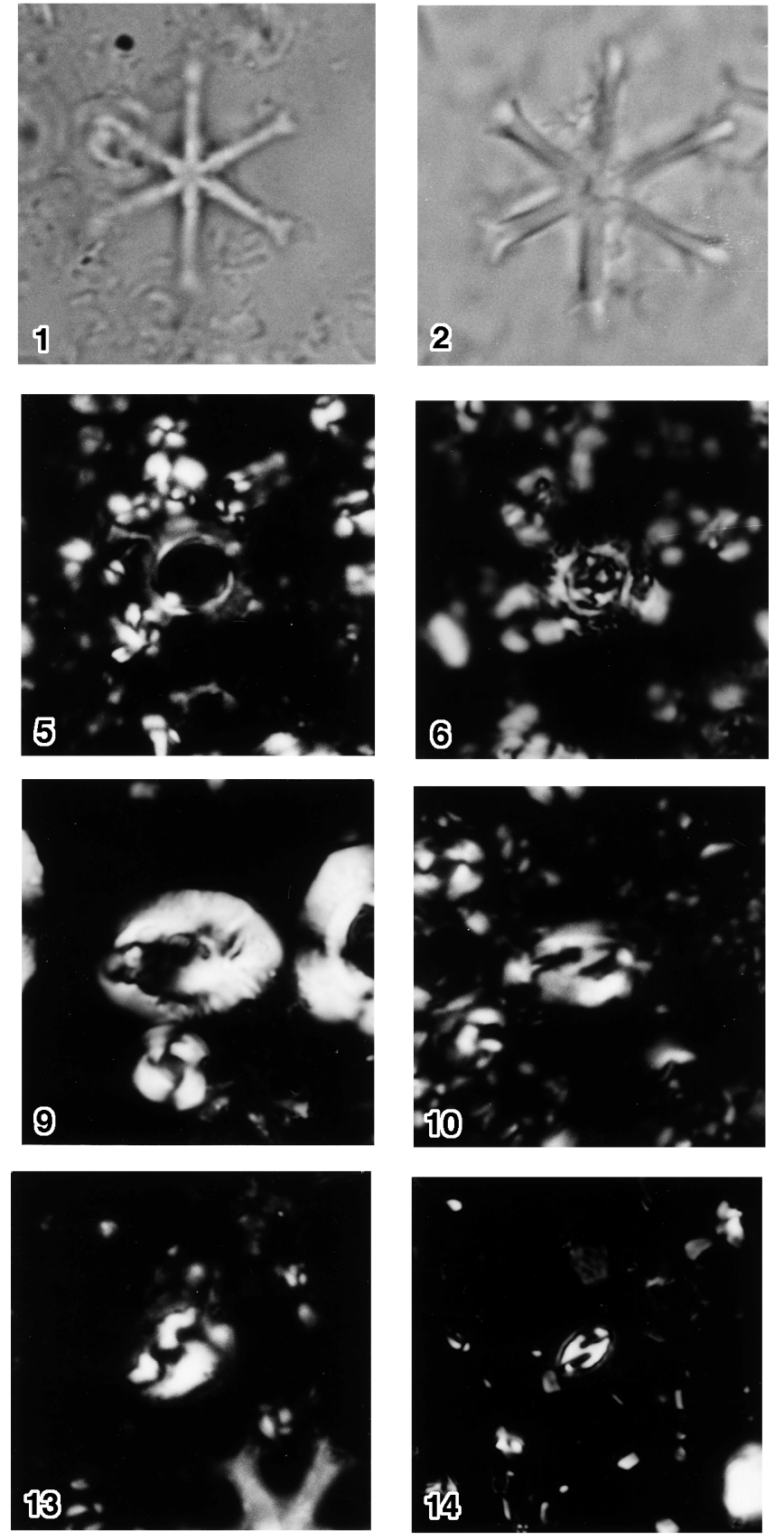
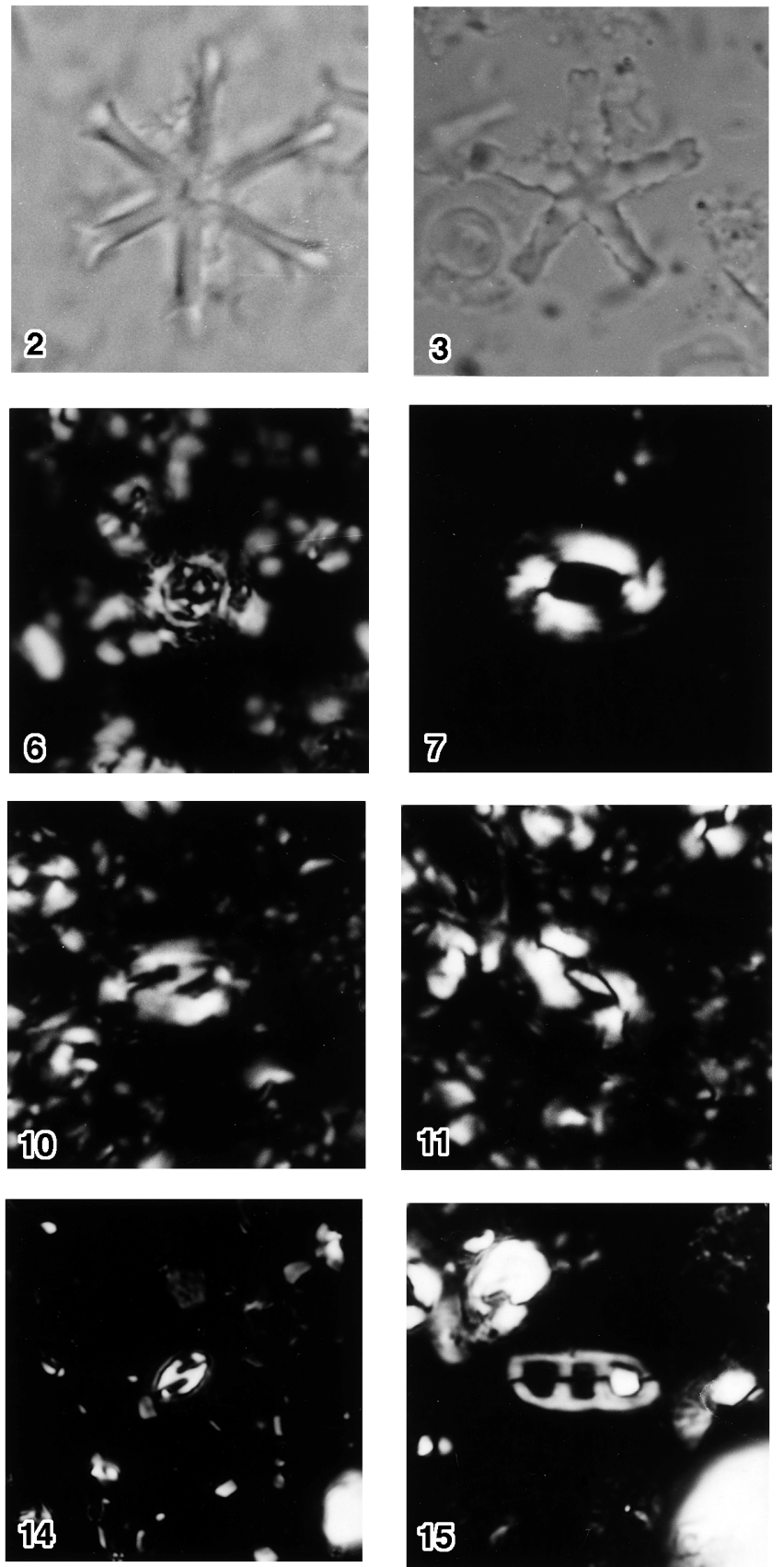
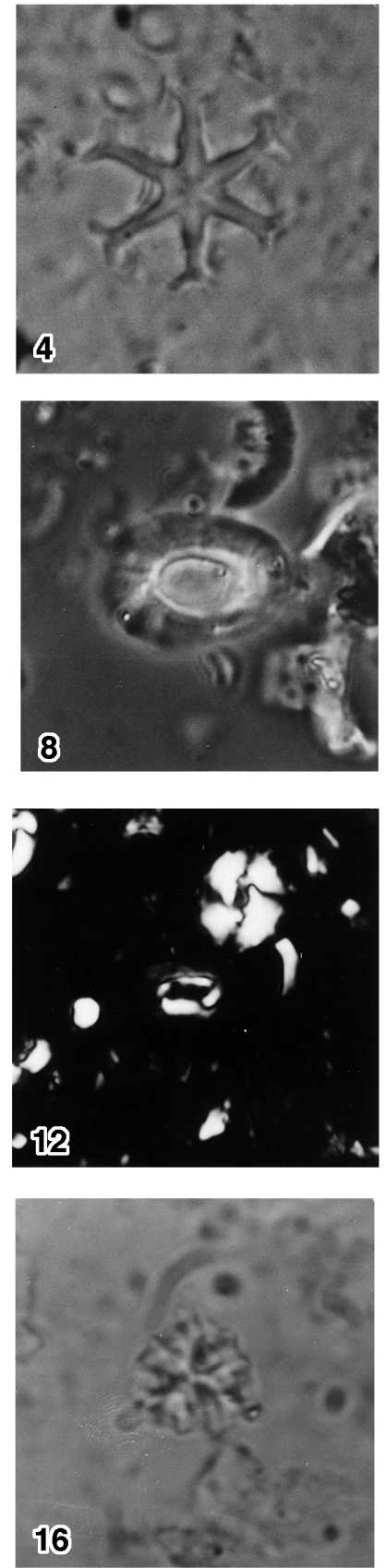

Plate 3. All photographs 1800×. 1. Discoaster signus, TL, Sample 157-952A-35X-6, $87 \mathrm{~cm}$. 2. D. surculus, TL, Sample 157-952A-23X-4, $41 \mathrm{~cm}$. 3. Discoaster tanii ssp. ornatus, TL, Sample 157-950A-39X-6, $130 \mathrm{~cm}$. 4. D. variabilis, TL, Sample 157-952A-25X-CC, $26 \mathrm{~cm}$. 5. Geminilithella rotula, XPL, Sample 157-952A-25X-CC, $26 \mathrm{~cm}$. 6. Hayella aperta, XPL, Sample 157-950A-31X-5, $56 \mathrm{~cm}$. 7, 8. Helicosphaera ampliaperta, 7. XPL, 8. PCL, Sample 157-952A-45X-6, 25 cm. 9. Helicosphaera compacta, XPL, Sample 157-950A-39X-6, $130 \mathrm{~cm}$. 10, 11. Helicosphaera euphratis, 10, 11. XPL, Sample 157-952A-25X-CC, 26 cm. 12. Helicosphaera orientalis, XPL, Sample 157-950A-28X-CC, $32 \mathrm{~cm}$. 13. Helicosphaera perch-nielsenae, XPL, Sample 157-952A-39X-3, 128 cm. 14. Helicosphaera stalis, XPL, Sample 157-950A-28X-CC, $32 \mathrm{~cm}$. 15. Isthmolithus recurvus, XPL, Sample 157-950A-39X-6, $130 \mathrm{~cm}$. 16. Lithostromation perdurum, TL, Sample 157-950A-28X-1, $30 \mathrm{~cm}$. 

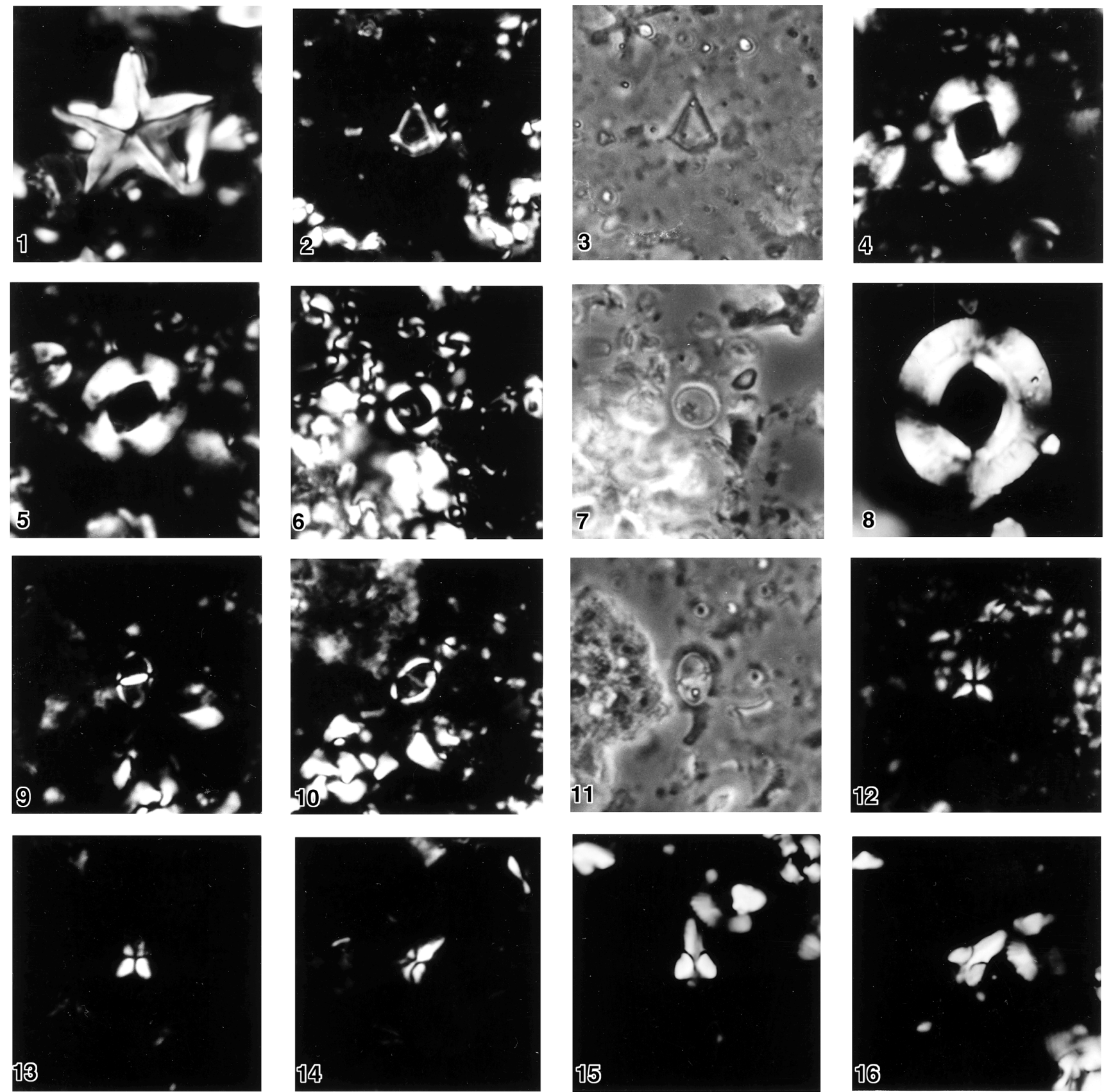

Plate 4. All photographs 1800×. 1. Micrantholithus flos, XPL, Sample 157-950A-37X-CC, $45 \mathrm{~cm}$. 2, 3. Minylitha convallis, 2. XPL, 3. PCL, Sample 157952A-26X-3, 96 cm. 4, 5. Reticulofenestra pseudoumbilicus, 4, 5. XPL, Sample 157-952A-31X-2, 64 cm. 6, 7. Reticulofenestra rotaria, 4. XPL, 5. PCL, Sample 157-952A-23X-5, 10 cm. 8. Reticulofenestra umbilicus, XPL, Sample 157-950A-40X-1, $70 \mathrm{~cm}$. 9-11. Solidopons petrae, 9, 10. XPL, 11. PCL, Sample 157-952A-31X-2, 64 cm. 12. Sphenolithus abies, XPL, Sample 157-952A-23X-4, $41 \mathrm{~cm} .13$, 14. Sphenolithus belemnos, 13, 14. XPL, Sample 157-952A-44X-6, 125 cm. 15, 16. Sphenolithus ciperoensis, 15, 16. XPL, Sample 157-950A-37X-CC, 45 cm. 

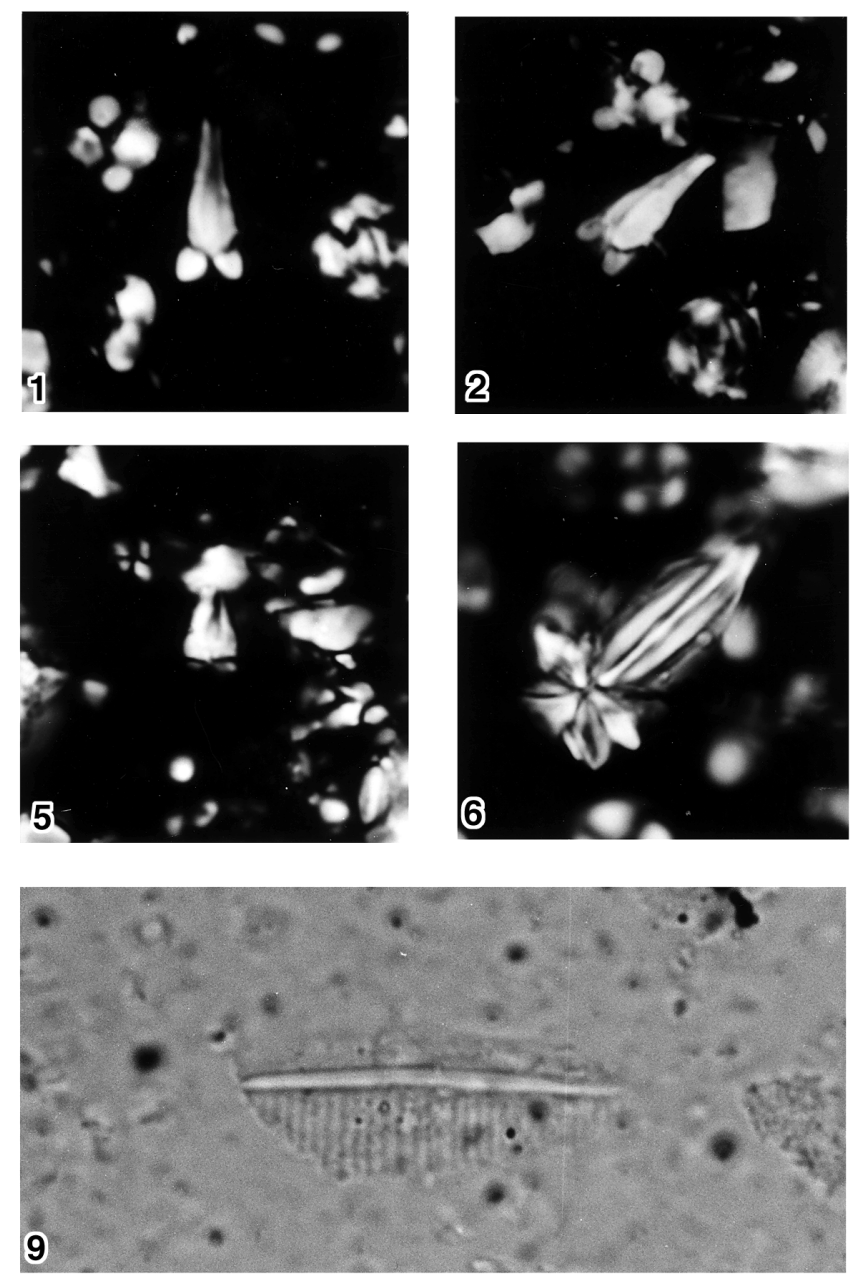
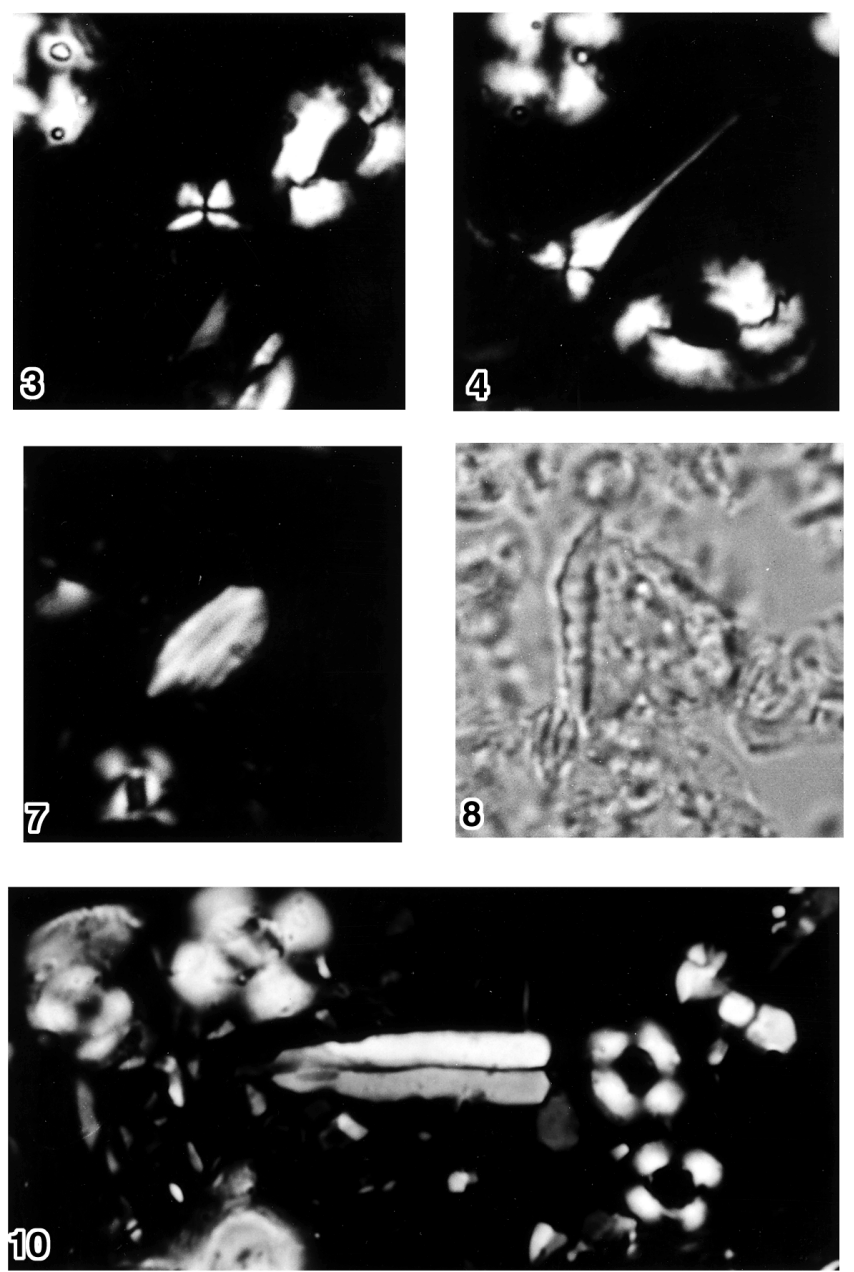

Plate 5. All photographs 1800×. 1, 2. Sphenolithus distentus, 1, 2. XPL, Sample 157-950A-37X-CC, 45 cm. 3, 4. Sphenolithus heteromorphus, 3, 4. XPL, Sample 157-952A-45X-6, 25 cm. 5. Sphenolithus predistentus, XPL, Sample 157-950A-37X-CC, 45 cm. 6. Sphenolithus pseudoradians, XPL, Sample 157-950A-38X-4, $88 \mathrm{~cm}$. 7. Triquetrorhabdulus challengeri, XPL, Sample 157-952A-33X-4, $87 \mathrm{~cm}$. 8. Triquetrorhabdulus extensus, TL, Sample 157952A-25X-6, 10 cm. 9. Triquetrorhabdulus rugosus, TL, Sample 157-952A-26X-3, 96 cm. 10. Zygrhablithus bijugatus, XPL, Sample 157-950A-37X-CC, $45 \mathrm{~cm}$. 